\title{
Chapter 8. From Domains to Rajadom: Notes on the History of Territorial Categories and Institutions in the Rajadom of Sikka
}

\section{E.D. Lewis}

\section{Introduction ${ }^{1}$}

Two forms of Sikkanese society can be distinguished in contemporary Kabupaten ${ }^{2}$ Sikka of eastern Flores on ethnological grounds. One is that of the Ata Tana 'Ai in the eastern region of the kabupaten. The other is that of central Sikka, which includes the villages of the central hills and mountains and the north and south coasts of the regency. ${ }^{3}$ The main difference between the two societies that will concern me here is this: whereas no secular polity ever developed in Tana 'Ai, by the beginning of the 20th century, the society of central Sikka constituted a local state, a single polity under the rule of a Sikkanese royal house, which traced its origins through 18 rajas and at least 16 generations. ${ }^{4}$ The Rajadom of Sikka dated at least to the Portuguese era in eastern Indonesia, evolved into a semi-autonomous state under the Dutch policy of zelfbestuur (self-rule) in the 19th and 20th centuries, and reached the apex of its power and independence in the absence of the Dutch Colonial Government in the decade immediately after World War II. Tana 'Ai came under direct Sikkanese rule only in the last three decades of the history of the Rajadom of Sikka. Indeed, Sikkanese rule had so little practical effect in Tana 'Ai that contemporary Ata Tana 'Ai still recognise five tana, or 'ceremonial domains', in their region today (see Map 1) and remember very little of the rajadom or its Sikkanese rulers.

In these two societies we thus see, recapitulated on the scale of a single Florenese region, a pattern characteristic of eastern Indonesia generally, whereby some societies gave rise to local states while others did not. In the case of Sikka, on a relatively local scale, the question becomes: how did Sikka become a state while the Ata Tana 'Ai retained a society founded on ceremonial domains? This is an ethnological and a historical question. Any advance towards an answer should contribute to solving two general problems in eastern Indonesian ethnology and history. Firstly, how did local states arise in eastern Indonesia? Secondly, why did some societies in eastern Indonesia develop into local states while others did not? 


\section{Map 1: Settlements and domains (tana) of Tana 'Ai}

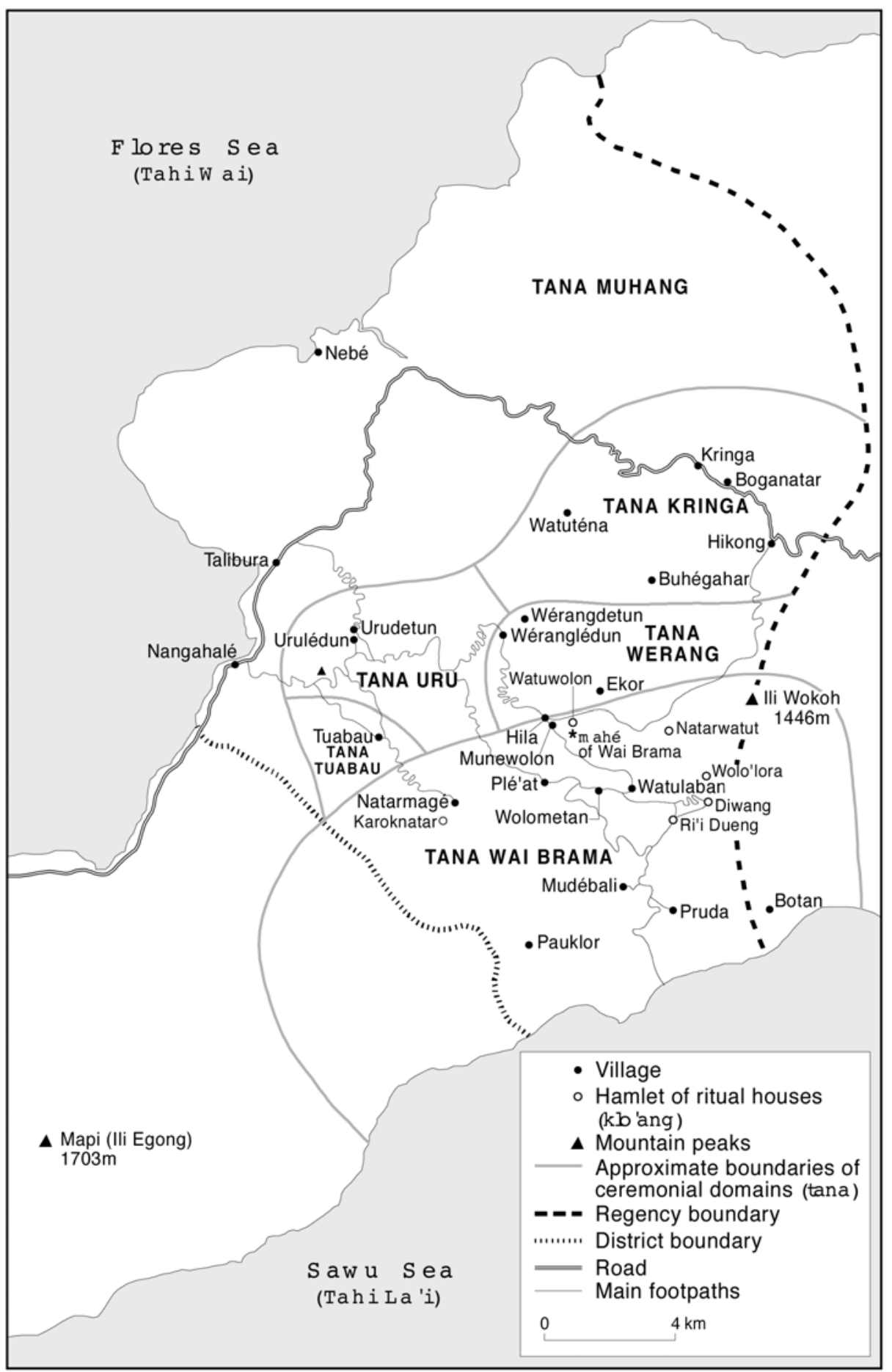


In examining the specific case of Kabupaten Sikka, I will make the following ethnological assumptions: 1) the nature and organisation of the Tana 'Ai domains did not change greatly during the two or three centuries in which the Sikkanese Rajadom evolved; and 2) despite differences between the societies of Tana 'Ai and Sikka, before the advent of the rajadom, Sikkanese communities were domain-based societies similar to those of Tana 'Ai. These assumptions are justified on the evidence of contemporary ethnographic research in Sikka, which includes oral histories of people in Sikka Natar (the village of Sikka on the south coast of Flores from which the rajadom and the contemporary kabupaten took their names), the myths of origin of the rajadom, and the origin myths of the immigrant groups who make up Sikka Natar.

I shall approach the Sikkanese case by addressing three questions: 1) What were the domains of Sikka like before the rajadom and the arrival of the Dutch? 2) How did the Sikkanese rulers establish their hegemony over central Sikka? And 3) what changes in territorial categories and institutions resulted from the evolution from domains to a rajadom in central Sikka?

I shall begin with a brief, comparative reference to the domains of Tana 'Ai in far eastern Sikka. I do this because I assume that the basic features of tana ('domains', in Sara Sikka [SS], the language of Sikka) in the area of Tana 'Ai were in the past also those of the tana of central Sikka.

\section{Tana as a Territorial Category in Tana 'Ai}

Domains (tana) in Tana 'Ai are the highest order of the classificatory categories of Tana 'Ai society. They are, in the broadest sense, religious in nature and ceremonial in manifestation. Leadership in a tana is, or was until recently, exercised mainly in the realm of sacred authority and ritual performance and the tana had no single secular authority. The Tana 'Ai pattern is best illustrated by features of the domain of Wai Brama, the largest of the tana of Tana 'Ai. In Wai Brama the most important decisions affecting the secular affairs of the domain's clans and houses are taken by the ina geté ('great mothers') of those clans and houses while men, as ritual specialists, carry out domain rituals on behalf of their sisters and mothers. As a society, Tana Wai Brama is defined by the relations of the clans which provide their members with land in the domain by virtue of the clans' positions in a system of precedence set out in the domain's myths of origin. ${ }^{5}$

Tana Wai Brama is a ceremonial domain headed by a tana pu'an, a 'source of the domain', who is always of the central house of the central clan in terms of the precedence of clans in the domain and houses in the clan. The central clan is credited with founding the domain in the mythic past. The tana pu'an is the head of a ceremonial system within which the clans of the tana must help organise, provision and conduct rituals of the domain. These rituals are the gren 
mahe and the rituals to open and close the dry and wet seasons. ${ }^{6}$ It is important to note that it is clan membership that entitles, indeed, requires, a person to discharge obligations in gren mahé, regardless of whether he or she resides at a place clearly within the domain's territory. Given that the clans are not themselves associated with demarcated territories, neither the clans of the domain nor the tana as a whole can be described strictly as territorial institutions. A tana is instead a loosely organised region defined by a centre, whose peripheries form no clear boundary. A tana's centre is defined ritually (if not geographically) by its mahé, the domain's central ceremonial site, and socially by the ceremonial office of the tana pu'an. Notwithstanding the delimitation of domain boundaries in Map 1, the domains are best thought of as social spaces defined by ritual centres whose influence and power extend radially and outwards until overshadowed by the power of neighbouring domains radiating from their centres. Thus, a person living on the frontier of two tana might have obligations in one gren by virtue of clan membership while participating in the gren of the other tana as a way of hedging his or her bets with respect to the fertility of gardens (which the gren ensures) or because he or she traces ancestral origins to a clan of that tana.

\section{Territorial Categories in Central Sikka}

Tana (SS), natar (SS), and negeri (BI) are three commonly used markers of territories in central Sikka but they are slippery words in Sikkanese discourse.

The word tana in Sara Sikka encompasses the following meanings:

1. niang tana: 'the earth, the world'. For example, ata teri niang 'era tana are 'the people who live (sit) on the land and arise (stand up) from the earth', and ata tawa tana, 'people who arose from the earth', are autochthons (BI orang asli ).

2. territory, district, region: tana Sikka is the 'region of Sikka', which is innately ambiguous insofar as Sikka refers variously to the village of Sikka, the Regency of Sikka, and the aggregate of domains that demarcated central Sikka from its neighbours to the east and west.

The word natar in Sara Sikka means:

1. kampung (BI: village). Thus Sikka, Natar is specifically the village of Sikka.

2. desa : 'village' in Bahasa Indonesia, but note that Wilkinson defines the word in Malay as 'region; country; country-village' and comments, 'a word used rather loosely, viz.: (i) of a territorial unit of any size ... (ii) of the country in contr[ast] to the townships ... (iii) in Java, a country hamlet; = (Mal[ay]) kampong' (Wilkinson 1959: 277-8). While not wishing to suggest that the Sikkanese speak Malay (much less an old form of Malay) rather than Bahasa Indonesia, use of the word desa in contemporary Kabupaten 
Sikka accords as well with Wilkinson's definitions as with modern Bahasa Indonesia, in which desa means 'village'. ${ }^{7}$

The word negeri is Malay and Bahasa Indonesia, but is used commonly in Sara Sikka and is used frequently in certain Sikkanese texts. Here matters become truly confused. In contemporary Bahasa Indonesia, negeri means 'country, land' (Echols and Shadily 1989: 386), but Echols and Shadily note that in Malay and in eastern Indonesia the word denotes 'village', an observation supported by recordings of Sikkanese speech and the word's use in early Sikkanese manuscripts. Noting the origin of the word in Sanskrit, Wilkinson defines negeri as

settlement; city-state ... used loosely (Mal[ay]) of any settlement, town or land ... more specifically (Min[angkabau]) of an autonomous area or group of villages under a penghulu andeka ... or other territorial chief, e.g. Negeri Sembilan (the 'Nine States', each autonomous though collectively under a suzerain). (Wilkinson 1959: 802)

I belabour the reader with these definitions because they are of key terms and because they warn us to take care about usage in context. The 'looseness' in usage that Wilkinson notes is firstly a matter of variation in the meaning of a single word across the Malay-Indonesian Archipelago and, secondly, a matter of lexical polysemy in the context of a single linguistic community. The pairs tana and natar in Sikkanese and negeri and desa in Indonesian are used commonly in Kabupaten Sikka and, more importantly for my purposes here, occur frequently in the Sikkanese texts from which I will draw evidence for territorial categories in central Sikka. It is thus crucial to be as certain as possible about the multiple meanings of the terms in the context of Sikkanese usage.

The inhabitants of some of the villages of central Sikka have preserved the ritual sites (mahé) which, in Tana 'Ai, would mark the centres of tana, ceremonial domains (Plates 1, 2 and 3), with this difference: whereas the mahé of Tana Wai Brama is in a clearing hidden within a stand of primary forest some distance from human habitation, the mahé of central Sikka are located in the centres of villages in public spaces reminiscent of the ritual sites of the societies of central and western Flores. These central Sikkanese sites can be taken as direct evidence for past ceremonial systems in central Sikka and as indirect evidence for the location of the centres of tana, which were perhaps similar to those of contemporary Tana 'Ai. ${ }^{8}$ 
Plate 1: Remains of Mahé Mo'ang Hi'eng at Héwoklo'ang (1979)

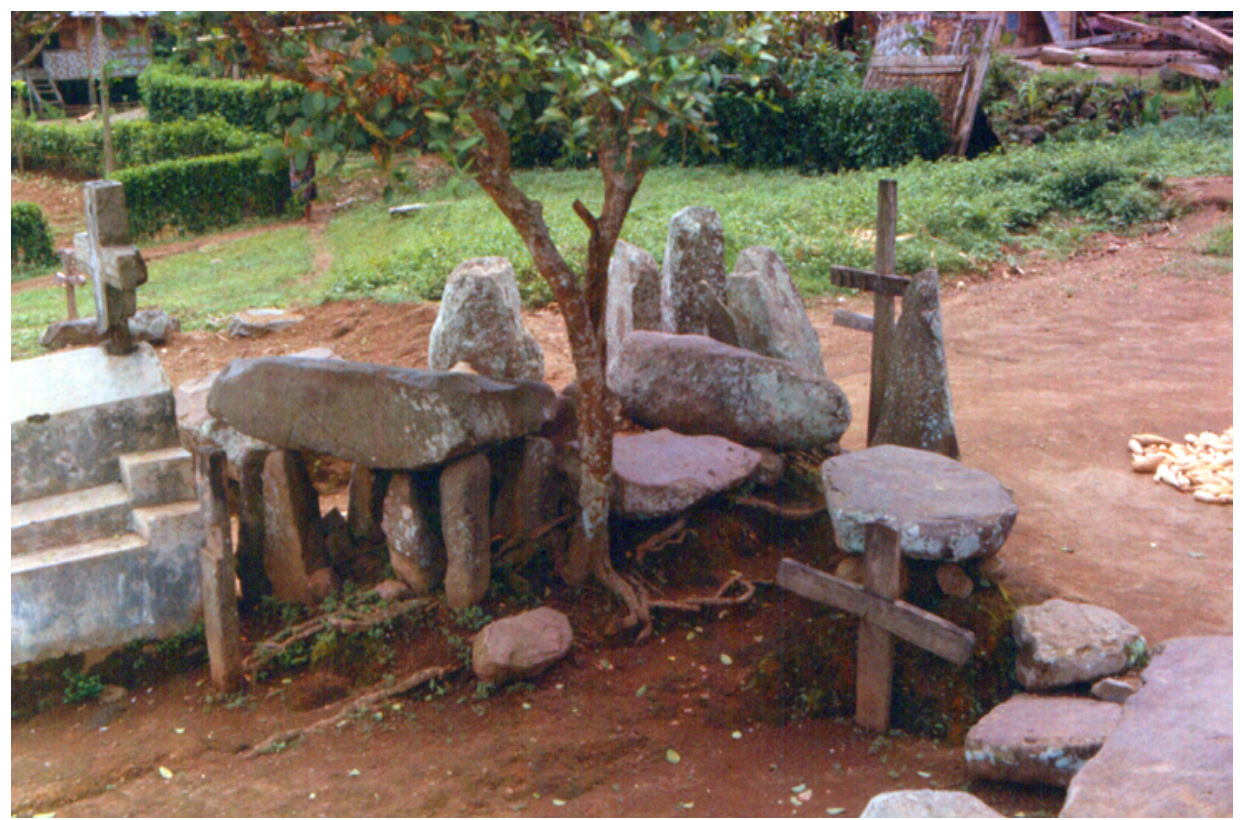

Plate 2: Remains of the Mahé at Baomékot (1979)

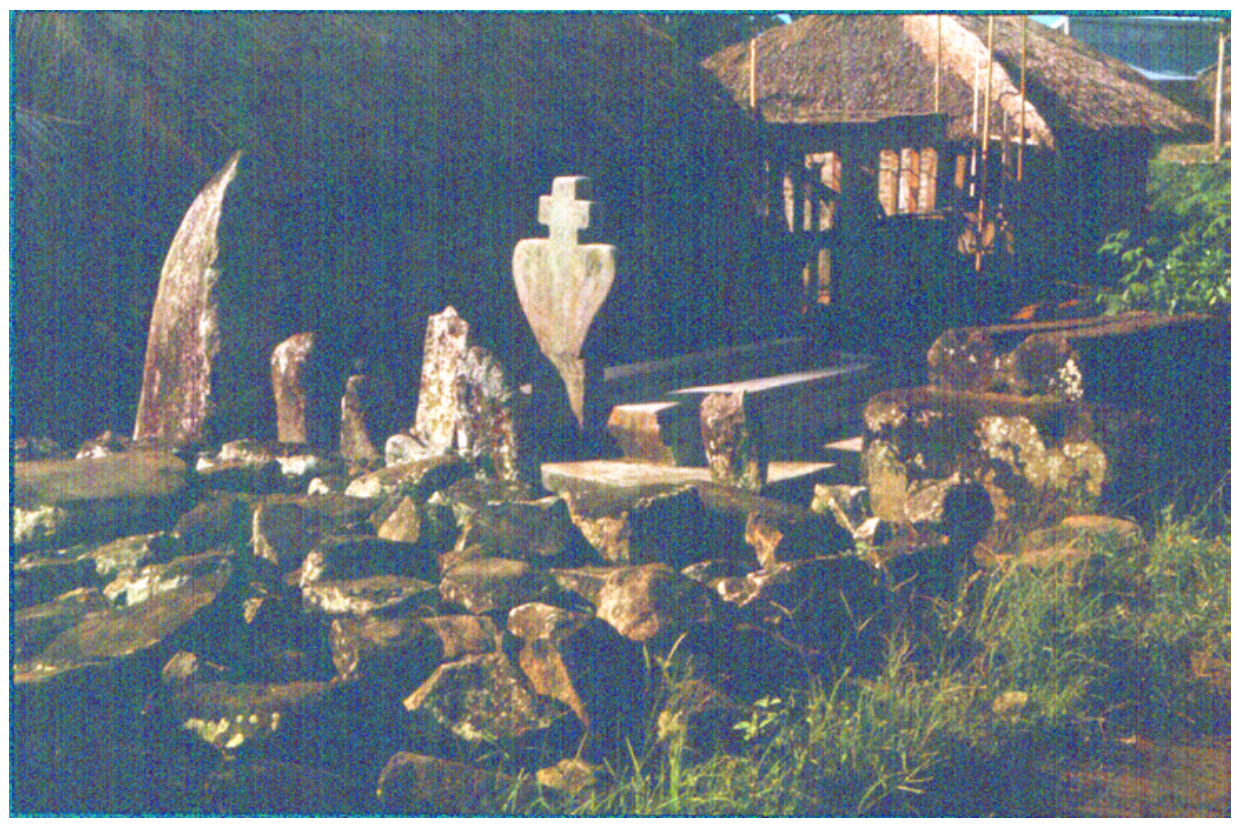


Plate 3: Remains of the Mahé at Kangae (2000)

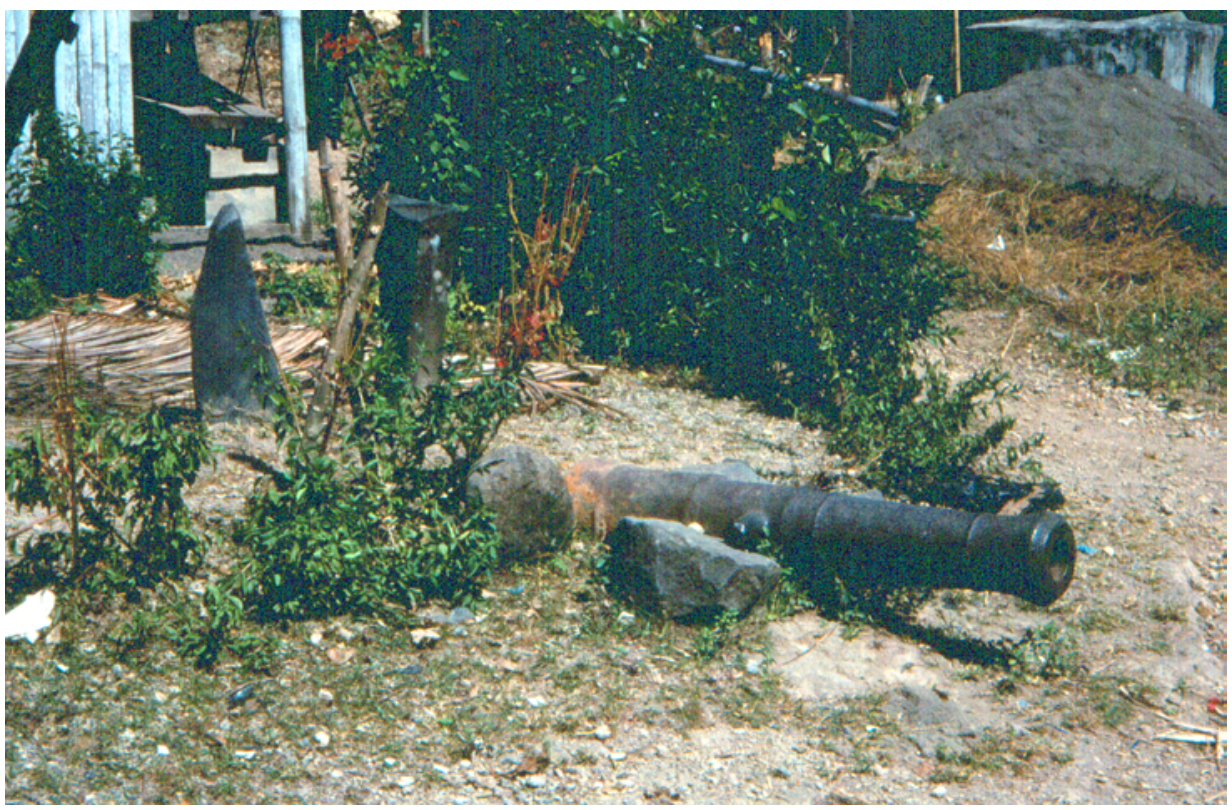

Plate 4: The organisation of the Rajadom of Sikka in the era of Mo'ang Don Alésu da Silva (Pareira unpublished [2002]: 12-13)

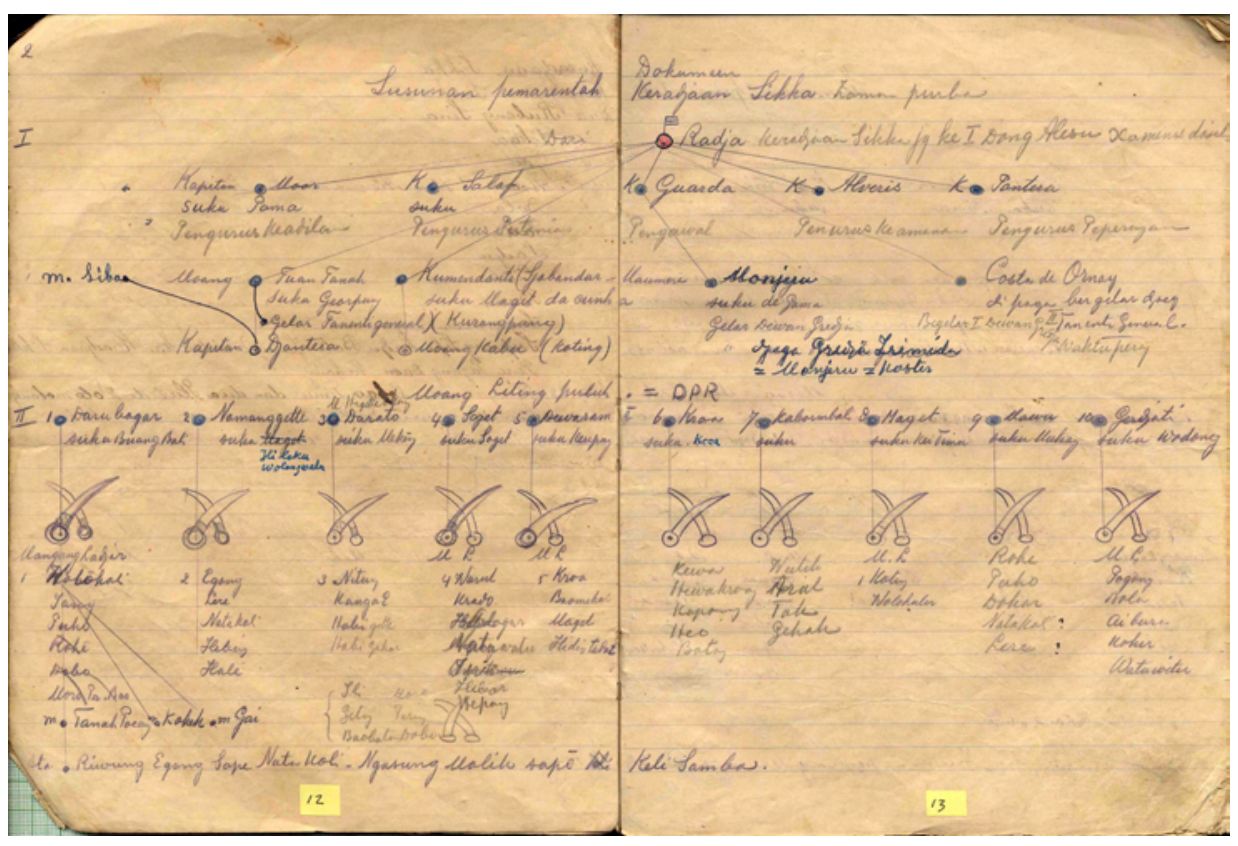


Additional evidence for territorial categories effective in Sikka's past designated by the terms tana, natar and negeri in central Sikka can be found in interviews with Sikkanese informants in the years 1977-2002 and, of particular value, in the narratives of the foundation myth and subsequent history of the Rajadom of Sikka, written by Mo'ang Alexius Boer Pareira and Mo'ang Dominicus Dionitius Parera Kondi, two Sikkanese authors of the first half of the 20th century. $^{9}$

One of Mo'ang Boer's notebooks (Document 001, Sikka Manuscripts Collection; Pareira unpublished [2002]) includes a rough chart (Plate 4 and Figure 1) ${ }^{10}$ of the organisation of the Rajadom of Sikka in the era of the first raja, Mo'ang Don Alésu Xamenes da Silva, a time undated in the history of the rajadom.

Figure 1: The Organisation of the Rajadom of Sikka in the Era of Mo'ang Don Alésu da Silva (after Pareira unpublished [2002]: 12-13)

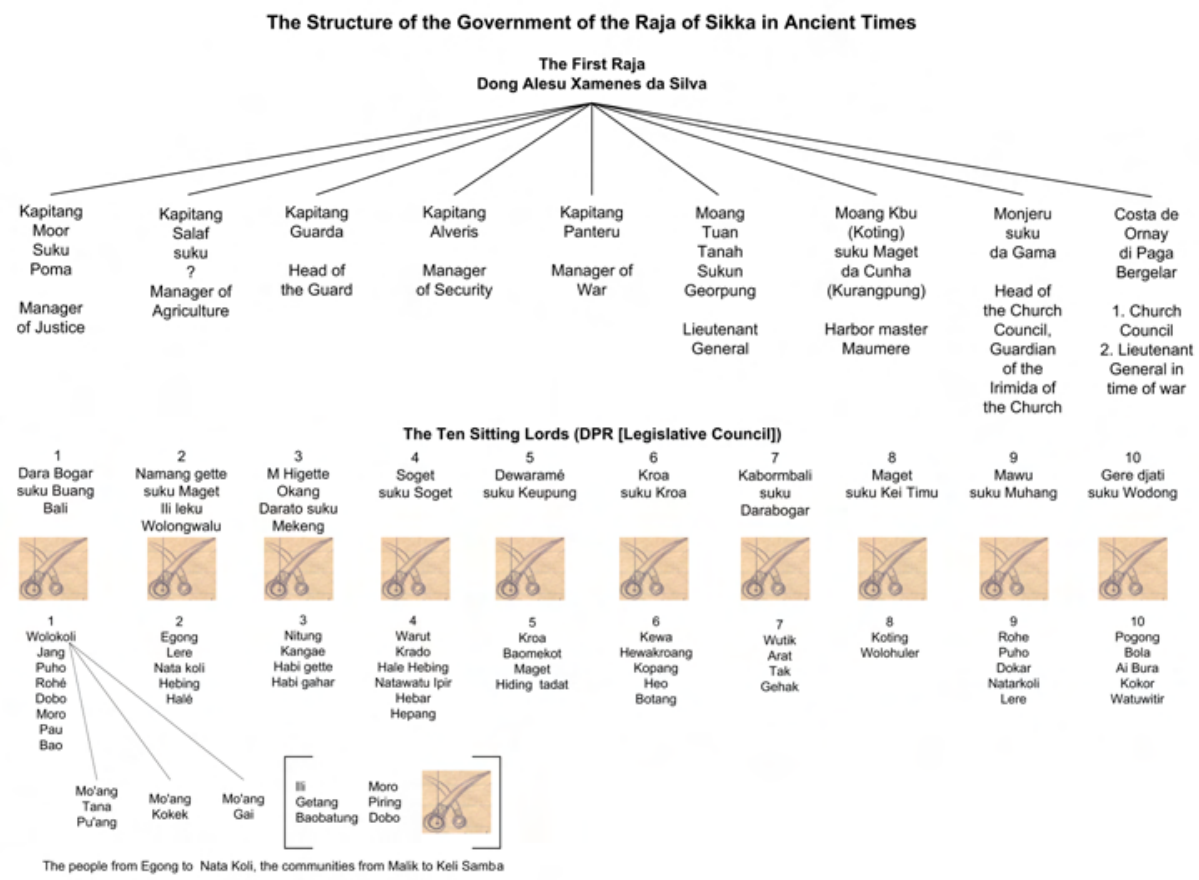

Mo'ang Boer's depiction of the structure of the Rajadom of Sikka 'in ancient times' indicates two levels of organisation. The first shows the relation of the first raja to eight office-holders called kapitang (captains) and indicates their responsibilities. Most of the kapitang were drawn from groups that Boer identifies as suku (SS 'clans') of Sikka Natar and from clans outside Sikka Natar that were allied closely with lepo geté (SS 'great house'), the royal house of Sikka. This is an interesting point because the people of contemporary Sikka Natar deny that they belong to clans and that suku are categories of Sikkanese society. ${ }^{11}$ They 
point out that Sikka Natar is divided into 'wisung wangang, which are extended family groups. The people of each 'wisung bear a Portuguese (P) name and are associated with households and territorial homesteads within the village.

In Boer's chart, the eight kapitang are shown as holding offices labelled by two Malay titles and six Portuguese titles. Five of the offices are identified as being associated with clan names or villages. Boer's list of the kapitang under Don Alésu, the first of the Sikkanese rajas, and explanatory notes about the meaning of the titles (from left to right in Boer's chart) are given below. ${ }^{12}$

Kapitang Moor: Pengurus From capitão mor (P): until the beginning of the 20th Keadilan (Manager of century, the commander of a Portuguese village Justice) militia.

Kapitang Salaf: Pengurus The origin of the title salaf is obscure, but three Pertanian (Manager of Agriculture) possibilities can be identified. 1) from capitão de sala or capitão de salas $(\mathrm{P})$, possibly a captain in charge of bureaucracy, provisions, supply, ordnance. 2) Salaf is not an Arabic word but might derive from safra (P), 'harvest'. It is possible that in borrowing this word the Sikkanese first changed it to *safara or *safala, which was further altered by metathesis ( *salafa) and the loss of the final vowel ( salaf). An alternative evolution might have involved a metathesis first (safra *serafa, *sarafa or *salafa) followed by the loss of the final $a$. Dr A.N. Baxter (personal communication) notes that the loss of the final vowel is curious since Sara Sikka allows both vowels and consonants at the end of syllables. A third possibility is that, in drawing on oral history as his source, Boer might have mistranscribed the word in his manuscript.

Kapitang Djantera, Source Djantera might derive from dianteira (P), 'vanguard'. of the Earth, Clan Georpung: Tanenti General (Lieutenant General) Boer wrote in Malay and used the orthography common in Indonesia in Dutch times in which $/ \mathrm{j} /$ was written $d j$ and $/ y /$ was written $j$ (sadja 'only', saja 'I'). Djantera would have been pronounced/jantera/ in speech, but Boer might have intended that the $j a$ in the word (which in the Dutch orthography has the sound /ia/) be pronounced as /ia/, the $j$ replacing the $i$ in dianteira. If this were the case, then the Sikkanese word would be pronounced/diantera/, but if he intended the $d j$ to be pronounced $/ \mathrm{j} /$, then the word would be pronounced/jantera/ and would have been altered from the Portuguese when it came into the Sikkanese language.

Kumandanti Sjabandar Syahbandar (Malay) is a harbour master.

Maumere 
Kapitang Guarda: Pengawal ('First', of people) (First Minister?)

Costa de Ornay of Paga, 'bergelar djrey', 'holds the office of djrey'

Kapitang Alveris: Pengurus keamanan (Manager of Safety, Security)

Kapitang panteru: Pengurus peperangan (Manager of War)
Kapitang Guarda from (P) capitão da guarda or 'captain of the guard'. Boer identifies this kapitang as 'monyeru' and with the Irimida. An irimida (SS) is erimida $(\mathrm{P})$, a chapel or small church usually built outside and some distance from a village. The word monjeru (in Boer's writing, pronounced /monyeru/) is somewhat puzzling. It might be related to monge (P), 'friar, brother of a Christian order'. Boer equates monjeru with koster (Dutch), 'sexton, verger' (Küster in German; Latin custos, 'guard, keeper'). Boer notes that this officer 'Gelar dewan gredja [sic] jaga gredja irimida', that is, 'holds office on the church council and looks after the church's chapel'.

Djrey: the combination of consonants djr (jr in modern orthography) does not exist in Malay or Bahasa Indonesia. However, the change from / di/ to /ji/ is common in Portuguese itself and in Portuguese creole languages and this term is almost certainly from de rei (P: 'of the king'). Boer describes the holder of this office as responsible for the church council and for serving as 'Tanenti General waktu perang', that is, 'lieutenant general in time of war'. The sense of the term might be that of a minister plenipotentiary.

In the Portuguese military, alferes was a rank between sargento and tenente. Boer equates kapitang alveris with pengurus keamanan (BI), 'manager of safety, security'.

The shift from /p/ to /f/ is common in Portuguese words borrowed by speakers of Malay and Tagalog and if this happened in Sikka, panteru might well derive from infante ( $\mathrm{P}$ : 'infantry soldier'). Baxter (personal communication) has suggested that in a purely local formation, infante (P) acquired the Portuguese agentive suffix -ero (which became eru in Sikkanese) to form a local Sikkanese word, panteru, meaning 'infantry' or, better, 'one who is involved with the infantry'. -Ero is highly productive in South-East Asian creole varieties of Portuguese, such as that of Malacca, and such a change in Sikka would not be surprising. In his chart, Boer equates kapitang panteru with 'pengurus peperangan' (BI), 'manager of war'.

Below these kapitang, or ministers, Boer identifies the Mo'ang Liting Puluh, Ten Sitting Lords, whom he describes as constituting a 'DPR' (BI: dewan perwakilan rakyat), a legislative council or legislative assembly. The Sitting Lords 
are identified further by clan and the negeri (villages and village clusters) which were their responsibilities.

The word 'liting (SS) means 1) 'base, foundation' and 2) 'chair', and in Sikkanese ritual speech there are references to

du'a deri é'i 'liting pulu the $d u^{\prime} a$ (honorific for women) who sits at the seven foundations;

mo'ang 'er é'i 'ler walu the mo'ang (honorific for men) who stands at the eight leaning places. ${ }^{\mathrm{a}}$

${ }^{\text {a } D u ' a ~ m o ' a n g ~ a r e ~ l e a d e r s ~ a n d ~ r i t u a l ~ s p e c i a l i s t s . ~}$

Boer identifies each of the Ten Sitting Lords not by name, but by clan affiliation. This identification is highly significant because the people of Sikka Natar are not, strictly speaking, divided into clans, whereas the people of the central hills of Sikka are. Below each Sitting Lord, Boer drew a pair of crossed elephant tusks. Ivory tusks were one of the main goods with which, according to the mythic histories of the rajadom, the early rajas secured alliances with the leaders of local communities in the central hills and mountains of Sikka (see Lewis 1998b, 1999). Below each of the 10 pairs of crossed tusks and clan names, Boer lists a number of villages in the following groupings:

\begin{tabular}{|c|c|c|c|}
\hline $\begin{array}{l}\text { 1. Wolokoli Iang } \\
\text { Puho Rohé } \\
\text { Dobo Moro } \\
\text { Pau Boa [= } \\
\text { Baot?] }\end{array}$ & $\begin{array}{l}\text { 4. Warut Krado } \\
\text { Halé Hébing } \\
\text { Nata Watu } \\
\text { Ipir Hébar } \\
\text { Hepang }\end{array}$ & $\begin{array}{l}\text { 7. Wutik Arat } \\
\text { Tak [Tok?] } \\
\text { Géhak }\end{array}$ & $\begin{array}{l}\text { 10. Pogong Bola } \\
\text { 'Ai Bura } \\
\text { Kokor Watu } \\
\text { Witir }\end{array}$ \\
\hline $\begin{array}{l}\text { 2. Egong Lere } \\
\text { Nata Koli } \\
\text { Hébing Halé }\end{array}$ & $\begin{array}{l}\text { 5. Kroa } \\
\text { Baomékot } \\
\text { Maget Hiding } \\
\text { Tadat }\end{array}$ & $\begin{array}{l}\text { 8. Koting Wolo } \\
\text { Huler }\end{array}$ & \\
\hline $\begin{array}{l}\text { 3. Nitung } \\
\text { Kangae Habi } \\
\text { Geté Habi } \\
\text { Gahar }\end{array}$ & $\begin{array}{l}\text { 6. Kéwa } \\
\text { Héwaklo'ang } \\
\text { Kopang } \\
\text { [Kopong] Héo } \\
\text { Botang }\end{array}$ & $\begin{array}{l}\text { 9. Rohé Puho } \\
\text { Dokar Natar } \\
\text { Koli Lere }\end{array}$ & \\
\hline
\end{tabular}

An 11th group of villages has been pencilled in below the main list:

11. Ili Gétang

Baobatung

Moro Piring

Dobo 
If duplicate names are ignored ${ }^{13}$ and the placenames are drawn onto a map of central Sikka, these 11 groups of villages form territorial clusters (Map 2). Although Boer does not do so in the document I have cited, I am strongly inclined to view the territories delimited by these clusters as tana, domains with which the early Sikkanese rulers treated during the era in which they created the rajadom.

\section{Map 2: Clusters of placenames and villages identified with the Ten Sitting Lords}

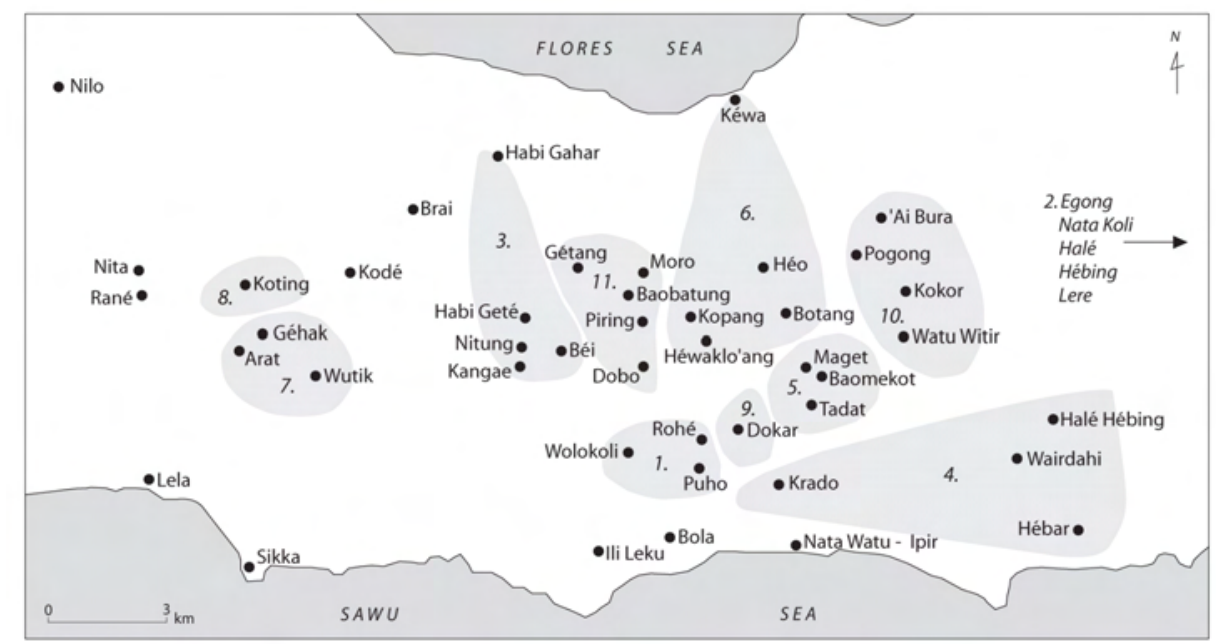

Towards the end of the notebook, Boer makes the following observation and appends a list of villages with which Raja Don Alésu made alliances (Pareira unpublished 2002):

Nora Don Alésu balong wawa Malaka mai dadi ratu é'i Niang Sikka te neti nora bala bala gawang gu mai bano néte natar baké na'i mangung ore na'i lajar. E'i Nuhang Ular tana lorang té'i é'i bahagian Tahi La'i sebela selatan molé é'i Tahi Wai sebela utara é'i natar natar wawa ba'u te'i.

There were Masts and Sails in the villages of:
1. Mudebali
16. Pora Nelu
17. Mage Panda
2. Runut
18. Manu Kako

When Don Alésu returned from Malaka and became Raja of the Land of Sikka he brought many elephant tusks which he then placed in the villages to raise up masts and sails. ${ }^{a}$ This he did on Snake Island [Flores], in the land between the Male Sea to the south and the Female Sea ${ }^{b}$ to the north, in many villages here.

31. Béi Nara

32. Ili Getang

33. Dobo Baobatung 


$\begin{array}{lllll}\text { 4. Egong } & \text { 19. } & \text { Wolosoko } & 34 . & \text { Kéwa Héwo Klo'ang } \\ \text { 5. Waidaki } & \text { 20. } & \text { Nua Lolo } & 35 . & \text { Ngalupolo } \\ \text { 6. Kroang Popot } & 21 . & \text { Natawulu } & 36 . & \text { Kota Ndona } \\ \text { 7. Warut Krado } & 22 . & \text { Nilo } & 37 . & \text { Masebewa } \\ \text { 8. Rohe } & 23 . & \text { Rane } & 38 . & \text { Kroa Baomekot } \\ \text { 9. Wolo Koli } & 24 . & \text { Koting } & 39 . & \text { Ngalu Poto Pogong Bola } \\ \text { 10. Ili Leku } & 25 . & \text { Wutik } & 40 . & \text { Wolomari (Lio) } \\ \text { 11. Mbengu } & 26 . & \text { Kailiwu } & 41 . & \text { Wolotopo } \\ \text { 12. Molik } & 27 . & \text { Kode } & 42 . & \text { Molik (Ndori) } \\ \text { 13. Rangga Se } & 28 . & \text { Brai } & 43 . & \text { Kota Jogo } \\ \text { 14. Wolowaru } & 29 . & \text { Habi Weko } & 44 . & \text { Wolo Mage Feondari } \\ \text { 15. Nggéla } & 30 . & \text { Nitung Kangae } & & \end{array}$

a The gift of twin elephant tusks, mangung lajar (mast and sail), to cement alliances between the rajas of Sikka and the negeri (villages) of the district, is a recurring theme in Boer's and Kondi's texts of the mythic histories of the Sikkanese rajadom.

b Tahi La'i (the Male Sea) and Tahi Wai (the Female Sea) are the Savu Sea and the Flores Sea, respectively.

Although much can be made of these lists, what should be noted immediately is that the structure of the raja's government depicted in Boer's diagram (Plate 4 and Figure 1) is not that of the raja's government under the Dutch. The arrangement of government in Dutch times was territorial: the kerajaan (BI: rajadom) was divided into a number of districts, each headed by a kapitang. The captaincies came to be (more or less) the first kecamatan ${ }^{14}$ in the early years of the Indonesian administration of Sikka, but note that the kecamatan have changed over the years since the introduction of the kabupaten system of government in the late 1950s and early 1960s. Boer's diagram does not mention districts, but depicts a unified and hierarchical system of government. The raja is at the apex. Next is the level of the ministers, who were drawn largely from the Sikkanese nobility. Below the ministers are the Ten Sitting Lords, who were the heads of villages or clusters of villages and who are depicted as an advisory council to the raja. At this level the system begins to appear territorial, but note that the territories were not headed by kapitang, who were appointed by the raja and were not necessarily from the districts over which they had authority, but by locals who might (in some instances) have been tana pu'ang.

In 1982, Dr J.K. Metzner published a detailed study of the geo-ecology of agriculture in central Sikka. That work includes a section on 'Traditional Land Tenure' in which Metzner provides a map of 'the chief traditional territories (tana) of the 'lord of the earth' (tana puang)' ${ }^{15}$ (Metzner 1982: 110; Map 3 below). The map is a reconstruction of the tana of Sikka in the "pre-contact era-that is until about the end of the nineteenth century' (Metzner 1982: 110). Metzner's 
reconstruction requires correction on many points, but the pattern he identifies can be taken, for the purposes of this paper, to be correct in its essentials. Metzner writes:

The size of a tana puang territory was essentially contingent upon population density. As [Map 3] shows[,] the tana puang territories were clearly smaller in densely populated Central Sikka than in eastern and western Sikka. The boundaries of these territories ... are not official, although they are sufficiently accurate in Central Sikka. ... [The map] thus serves to convey an approximate idea of former adat ${ }^{16}$ territories. In one of the most densely populated portions of central Sikka-at the saddle of Nita and around Maumere-however, it was not possible to delineate unequivocally the borders of such territories. (Metzner 1982: 111-3). ${ }^{17}$

\section{Map 3: Metzner's reconstruction of the tana of Central Sikka. ${ }^{18}$}

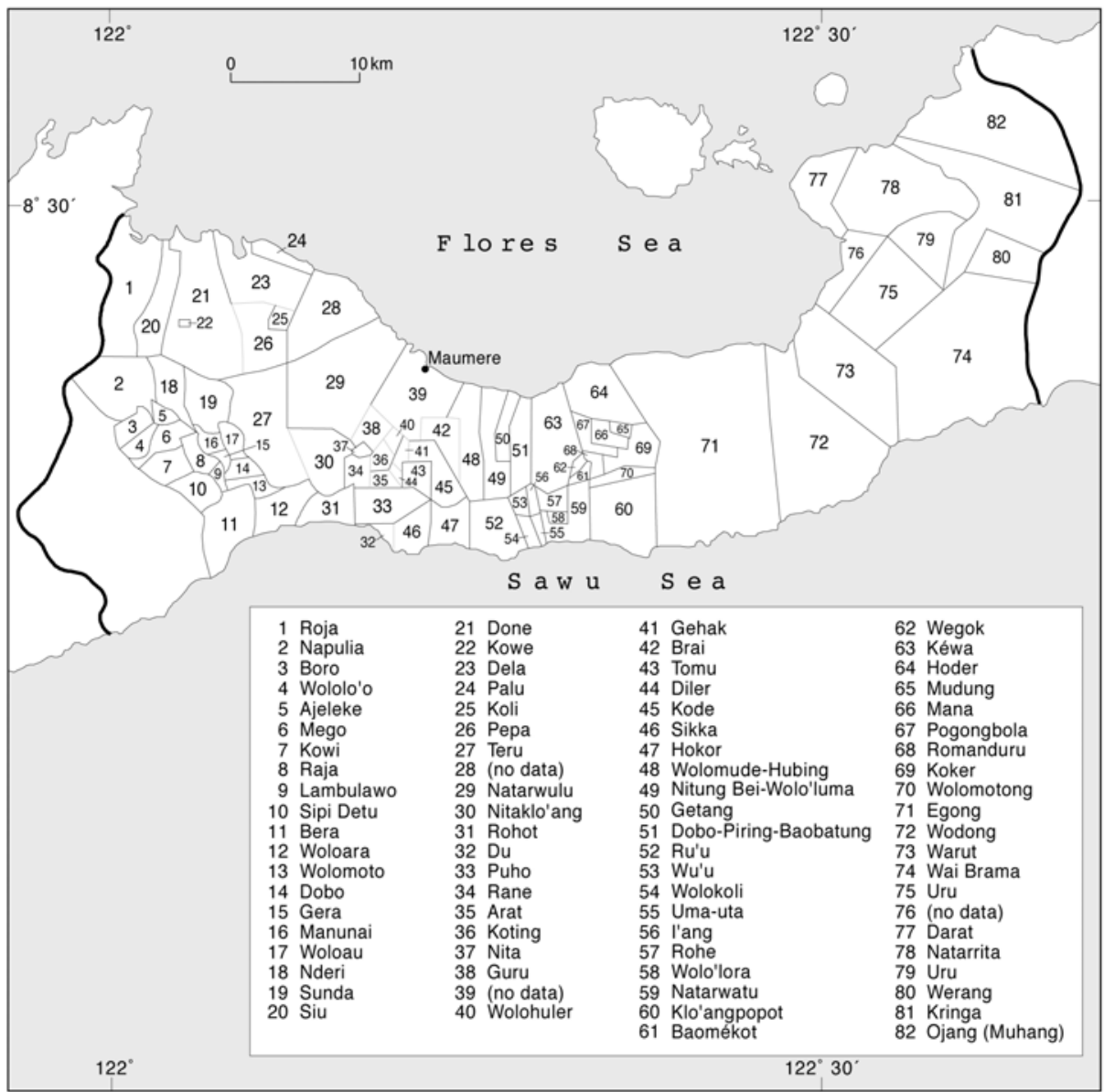


If we somewhat arbitrarily exclude the mainly Lionese regions of western Sikka and Tana 'Ai in the east from consideration and limit our focus to the tana of the central region of Metzner's map, ${ }^{19}$ we find 48 tana. Comparing the names of tana on Metzner's map with the 44 names provided by Boer in his list of mangung lajar villages, we find the concordance between Metzner's and Boer's enumerations of places likely to have been considered tana is only 13 names. Despite confusion about the names of the tana and some errors in Metzner's spelling of tana names, it is striking that the numbers of tana listed by Boer and Metzner (44 and 48, respectively) are very nearly the same.

Metzner's suggestion that the number of tana in the densely populated central region of Sikka was strikingly greater than in the eastern and western reaches of the rajadom was justifiable. As Metzner implies, it might well have been the case that as the population and population density of the central region increased through time, older and larger tana might have fragmented into smaller domains with the result that the number of tana in the region increased in the course of Sikka's history. If this were the case, we glimpse a dynamic and changing array of domains, which is in marked contrast with the situation in Tana 'Ai, whose oral histories represent the domains of the region as unchanged since their creation.

\section{Tana and the Creation of the Sikkanese Polity}

There is an old idea in the ethnology of South-East Asia about the differences between lowland or coastal peoples and the peoples of the interior highlands. This distinction between lowland and highland peoples is condensed in the title of Robbins Burling's book on South-East Asian cultures; Hill Farms and Padi Fields (1965). In Burling's conception,

... each country in southeast Asia has both hill people and plains people, and the contrast - and sometimes conflict - between the two ways of life can provide a theme which helps to bring order into our understanding of the area. (Burling 1965: 4)

The peoples of the relatively densely populated lowlands are culturally homogeneous wet-rice cultivators who are adherents to one of the universal religions; the hill people, 'who are always far more heterogeneous', speak different languages, have no political unity among themselves, and practice shifting cultivation (ibid.). ${ }^{20}$ With due respect to Burling, in Kabupaten Sikka, lowland and coastal people tend to view their highland cousins as just that: somewhat coarse, not completely Catholic, uneducated, a bit simple, and barefoot, but nevertheless their cousins. As an educated Sikkanese man once told me in the course of a conversation about the differences between his people and the Ata Tana 'Ai, 'They are still what we once were.' 21 
We can distinguish, as do the coastal Sikkanese themselves, three varieties of Sikkanese people: the Ata Tana 'Ai of the eastern valleys, the Ata 'Iwang (the phrase means orang udik [BI: person from a rural village; hillbilly] or, somewhat less pejoratively, orang pedalaman [BI: person of the back country] ${ }^{22}$ ) of the central hills, and, roughly, the southern and coastal Sikkanese, that is the people of the skewed crescent-shaped region from Nita in the west southward to Léla on the south coast, through Sikka Natar, to Bola in the east. Of these ethnonyms, the Ata Tana 'Ai call themselves Ata Tana 'Ai (at least, they acquiesce when others call them that) and the Sikkanese call themselves Ata Sikka (but, then, so does everyone in the district); but the Ata 'Iwang do not call themselves Ata 'Iwang: who, after all, refers to himself by saying, 'I am a heathen hillbilly'?

There is a small, fourth group: the ruling Sikkanese. In the district of Sikka, a ruling house arose on the south coast of Flores, in the village of Sikka. The house was Lepo Geté, the Great House, and its people used the name da Silva. The rulers it produced were known as ratu (rajas). This designation 'ruling Sikkanese' is easily quarrelled with because just who these early Sikkanese rulers were is something of a problem. All of the people of Sikka agree that the people of the ruling house are Sikkanese, but according to their own myth of origin, they are not. That myth tells the story of how, long ago, a sailing ship was wrecked on the south coast of Flores near Sikka Natar. Its crew, who were from 'Siam' (or 'Sailan', depending on the version of the myth one has to hand), could not repair their vessel, and so they took up residence on Flores. They met the orang asli (BI: 'aboriginal people') in the hills, with whom they made alliances. The myth relates the subterfuge by which, later on, the immigrants seized Sikka Natar from its aboriginal inhabitants and how immigrants from other parts of Flores and from farther away settled in Sikka to create a confederation of immigrant houses from which the whole of the region came to be ruled. In other words, the 'ruling' Sikkanese were immigrants; they were all 'new' Sikkanese. ${ }^{23}$

In one of the most important episodes in the myth, one of the descendants of the marooned ship's crew, Don Alésu, travelled to Malaka, where he 'studied ilmu politik [BI: 'political science']' and became a Christian. On his return, he and a travelling companion brought Catholicism to Sikka and founded the Rajadom of Sikka. If we jump forward to the end of the 19th century, we find Alésu's descendants ruling Kerajaan Sikka with authority delegated by the Dutch. ${ }^{24}$ This Alésu's descendants did until 1954. Sikka is thus a good example of the process of formation of a state which incorporated rulers on the coast who had direct links to the outside world and people of a hinterland who, while absorbed into the state, were not at its political centre.

Whereas the Ata Tana 'Ai preserved much of their hadat and have continued practising the rituals of their ceremonial system, which are the essence of their tana, during the past two or three centuries, the tana pu'ang of central Sikka 
lost their power and Christian symbols were added to the mahe of the region (see Plates 1, 2 and 3). In the same centuries, the people of Sikka Natar took Portuguese names and developed a state; 1) whose office-holders took titles that reflected Sikkanese perceptions of Portuguese organisations in eastern Indonesia, including ranks of the Portuguese military hierarchy; 2) whose efflorescence coincided historically with the rise of Dutch dominance in Flores; 3) whose foundation, as recounted in the mythic histories of the rajadom, coincided with the introduction of Catholicism in Sikka; and 4) whose development paralleled that of the Catholic Church on Flores. But more is required to understand what happened to Sikka's tana.

The tana of central Sikka (and their tana pu'ang) were not displaced entirely under the rajas' rule. Boer's diagram of the structure of the rajadom under Don Alésu is crucial evidence bearing on this question. The chart identifies localities and clusters of villages which were allied to the new rulers. Boer's and Kondi's histories tell us how these allegiances were secured and how the alliances were formed. The diagram also depicts graphically the imposition of a hierarchical system of governance over what theretofore had been autonomous local domains, a system imposed (according to Boer and Kondi) by an alien, immigrant people, according to an alien, Portuguese system of organisation, and, later, condoned by the alien, Dutch Colonial Government.

A central clue to what happened to the tana of Sikka is to be found not in what is in Boer's diagram, but what is not. Boer connects the raja and his ministers with lines that indicate their relationships. He connects the tana pu'ang to the villages under their authority with vertical lines, but there are no direct connections between the offices of the rajadom and the tana pu'ang identified on the chart. Furthermore (and somewhat puzzling), the crossed elephant tusks of the diagram, which indicate alliances, are not placed between the rajadom and the tana, but between the clans named as pu'ang and the territories associated with them.

This evidence points to a simple hypothesis: the rajas did not directly interfere with Sikkanese tana but, through time, usurped the tana pu'ang by incorporating them as lowest-level functionaries in the rajadom's government. As the Church and rajadom grew in power and influence in the district, the ritual importance of the tana pu'ang and thus their tana as territorial institutions simply withered away, although the concept of the tana as a ceremonial domain that bound its people together in a small-scale community remained. This progression was in most respects complete by the time the rajadom came to an end in 1954, and the tana as a territorial institution did not survive the transition to the modern government in the regency.

Not only did the immigrant rulers of Sikka usurp whatever local authority might have existed among the indigenous Sikkanese, the origin myth of the 
Sikkanese ruling house makes the claim that the immigrant rulers created the tana and tana pu'ang of central Sikka. Three key passages from the Hikayat Kerajaan Sikka (The History of the Rajadom of Sikka) illuminate this claim:

In the beginning, because of his wise policy, his majesty the Raja of Sikka ordered every tribe of the interior, those who were wealthy and brave, to a meeting in which they were given offices by his majesty the Raja along with the titles Mo'ang and Kapitan; each tribe had such an officer and they lived continually in the nation of Sikka. Thus the nation's origins were in the interior and outside and as each became an ally of the nation, they were governed by the Raja and the Raja took decisions about matters to make the nation safe and its allied villages in the interior with their Tana $\mathrm{Pu}^{\prime}$ ang ... and Kapitan whom he had appointed in the interior. (Kondi 2001: 7)

Secondly,

In his lifetime, Mo'ang Bata Jawa sailed here and there, obtaining on his journeys large plates which he then brought home to his country. ${ }^{25}$ After returning, he visited all the inhabitants of his territory, telling them: 'We human beings must have a God, from whom we ask assistance. Thus there must be a place for making offerings. So the plates which I have brought I must divide among all the negeri [i.e., tana] and designate in each a tana pu'ang (Source of the Earth).' (Kondi 2001: 27)

Finally, as recounted in Kondi's Hikayat Kerajaan Sikka, Mo'ang Baga Ngang, the third of Sikka's 'proto-rajas', appointed tana pu'ang and created tana. Kondi tells how Baga Ngang went around central Flores making alliances with the 'tribes' of the interior of the island:

Mo'ang Baga asked: 'Who is your leader?' They replied: 'We here do not have a leader.' Mo'ang Baga said: 'When you have a dispute, who unravels and decides the matter?' They replied: 'There is no one. Whoever happens to be present mediates our quarrels. And if we do not accede, it is just left so and whoever is strongest is the one who wins.' Mo'ang Baga said: 'In that case, there is no order. I will choose a person for you who will be your leader.' ... After that Mo'ang Baga praised them, saying that 'I along with my companions have come from Nata Gahar [High or Great Village] wishing to visit you here ... Perhaps you know who among you is the most respected and who was the first to come and open a garden and to live here?' Then two men stepped forward and faced Mo'ang Baga, saying: 'We are the two who originally came here and we are also the two who are most respected.' Mo'ang Baga replied: 'Good. This one is appointed as Source of the Earth and is to be called by the title tana pu'ang; he is the one who will make offerings on 
the altar (watu mahé) whenever you make a feast for opening a new garden, require the healing of illness, marry, build a new house, and for other things. You must bring offerings and when there is a dispute, just go to him.' ... Then Mo'ang Baga took a little of the heart of a pig, some rice, and gin and placed them atop the altar, which Mo'ang Baga had ordered constructed as an example for the Source of the Earth [tana pu'ang]. After finishing these things mentioned above, the people began serving food to entertain Mo'ang Baga and his companions. (Kondi 2001: 31- 2)

The most curious thing about these passages is that these mythic proto-rajas are credited with creating something that must already have existed: the ceremonial domains and the tana pu'ang who headed them.

\section{Portuguese Missions and Administrative Territories Created by the Dutch}

The earliest European presence on Flores was that of the Portuguese, who established missions around the contemporary town of Larantuka at the eastern end of Flores and on the islands of Adonara and Solor. ${ }^{26}$ Not long afterward, at least seven Portuguese mission stations were established on the island of Ende and on the coast of Ende Bay. ${ }^{27}$ Between Larantuka and Ende, the Portuguese presence was sparser, but Visser (1925: 292) locates two stations on the north coast of central Flores, at Dondo on the western end of Maumere Bay and at 'Krove' on the north coast near contemporary Nebé. ${ }^{28}$ According to Visser, the station at Krowé was founded between the years 1561 and 1575.

In addition, Visser cites evidence that Paga in the south-western reaches of Kabupaten Sikka and Sikka Natar itself were the sites of such stations on the south coast. While there is only a vague tradition among the contemporary people of Sikka Natar that their village was the site of a Dominican mission station, as Visser reports, it is possible that the village was, if not a Dominican station, then at least a place visited more or less regularly by Dominicans embarked on the Portuguese ships that passed along Flores's south coast. Visser's source 29 identifies the station at Sikka as a 'parochie' bearing the name Saint Lucia, and as a congregation numbering 1,000 souls in 1598. 30

The earliest mention of Sikka I have found in the literature is that in an unattributed description of the first Christians of the islands of Solor and Timor, which de Sá includes in his compilations of documents from the period 1568-79 relating to the history of Portuguese missions in the Orient: 


\section{Map 4: Dominican mission stations on Flores, Adonara and Solor in the 16th century (after Visser 1925: 292)}

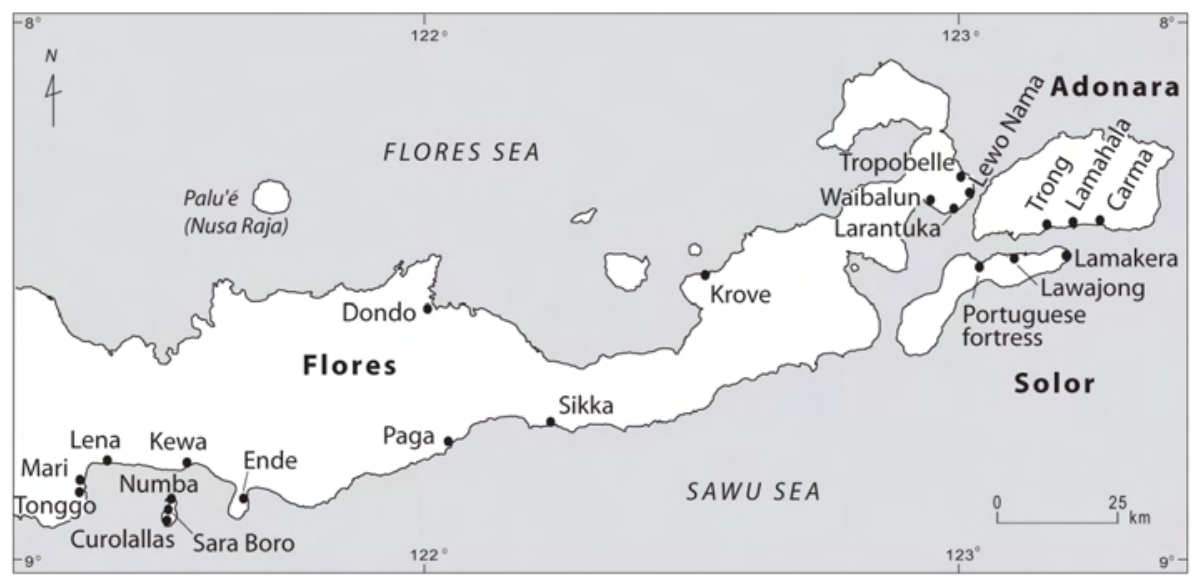

On this island of Larantuka, there would be fifteen leagues between the main settlement, that is referred to by the same name [i.e., Larantuka], and another that is further ahead on the island, called Siqua [Sikka], and another called Pagua [Paga]. Ende is another fifteen leagues beyond. All are Christian settlements, of one thousand firearms, and the majority, in addition to many other Christians and pagans, are our friends, having the aforesaid weapons. ${ }^{31}$

Just how frequent and intense was the contact between the Sikkanese and the Dominicans in the 16th and 17th centuries is an important question for which I have no answer. But it is likely that the contacts, and thus the direct influence of the Portuguese on the locals, were mainly on the coasts. Having said this, surely some Portuguese must have ventured inland from time to time (as from Krowé south into Tana 'Ai?) and surely people from the interior must have travelled to the coasts, if only to have a look at the foreigners - no place in east central Flores being more than a day's walk from the north or the south coasts. Evidence for at least indirect Portuguese influence in the interior is strong. For example, a small number of not-too-mangled Portuguese words turn up in transcriptions of ritual speech I recorded in Tana Wai Brama in the 1970s and 1980s.

The Dutch acquired Flores from the Portuguese in 1859 but it was some years before they became sufficiently interested in the region of Sikka to send a government official there. When that happened in the 1870s, the official settled not in Sikka Natar, the Village of Sikka on the south coast and the home of the rajas, but at Maumere on the north coast. Maumere was then a low-lying, hot, malarial place, sodden in the rainy season and smoky and dusty in the dry. It has since grown into one of the largest towns on Flores, a centre of education, 
and, with its excellent harbour and landing strip, a major port of entry for Flores and a commercial centre.

According to Dutch records and the hikayat of Kondi and Boer, much shuffling of allegiances and shifting of local negeri (villages, but in the hikayat, clearly the Malay equivalent of tana, 'domains') between the two (and for a while, three) rajadoms of Sikka went on in the two centuries before 1925. One effect of the shifting of negeri (each of which was probably a tana with its own tana pu'ang) and the rise of Sikka as a secular polity under the rajas of Sikka was to erode the importance of what the early Dutch records call tana pu'ang-schappen (tana pu'ang-ships). Once this process of incorporation into the rajadom and erosion of the tana pu'angs' authority was complete-by about 1950 - the local tana pu'ang retained respect in their communities, but no longer exercised any real power.

Here we encounter the limitations of the scarce historical sources on the early culture and history of Sikka and a peculiarity of the voluminous later manuscripts written by Sikkanese authors. Briefly, the problem is this: the authors of the first texts written by a few men of the first or second literate generation of Sikkanese were all officials in the government of the Rajadom of Sikka. The two major texts from that era, one by D.D.P. Kondi and the other by A. Boer Pareira, treat the history of Sikka in detail, but from the distinctive point of view of Lepo Geté, the 'Great House', the Royal House of Sikka. Since the people of Lepo Geté are, according to their own myth of origin, immigrants to Flores and by no means indigenes, their history cannot be taken to be the history of the indigenous Sikkanese peoples, which remains a subject about which we know very little. Furthermore, even the main outlines of the internal divisions of the Sikkanese people into communities is obscured, firstly by the Dutch, who created the administrative districts of the rajadom, and then by the early Sikkanese authors, who were little concerned with explaining the territorial categories and institutions of the indigenous social landscape but were concerned centrally with the creation of the Sikkanese rajadom and the legitimation of its rule.

Although information about early Dutch activity in Sikka is sketchy at best, we can get at least a general idea of what was going on in the old rajadom between about 1860 and 1942. Indeed, the picture becomes a bit more detailed once the Dutch, with their penchant for archiving the memories van overgave of their officials, arrived in Sikka. ${ }^{32}$

The Dutch administrative divisions of Flores, which must quickly have become territorial categories in the minds of the Florenese ('I am of Ende', 'He is from Sikka Maumere', 'They are Larantukans'), changed often in the years from 1879 until 1942, when the Dutch flag over Flores was replaced briefly with the Japanese rising sun. From 1879 to 1907, these were the administrative divisions of Flores (Map 5): 


\section{Map 5: Dutch administrative divisions of Flores, 1879-1907}

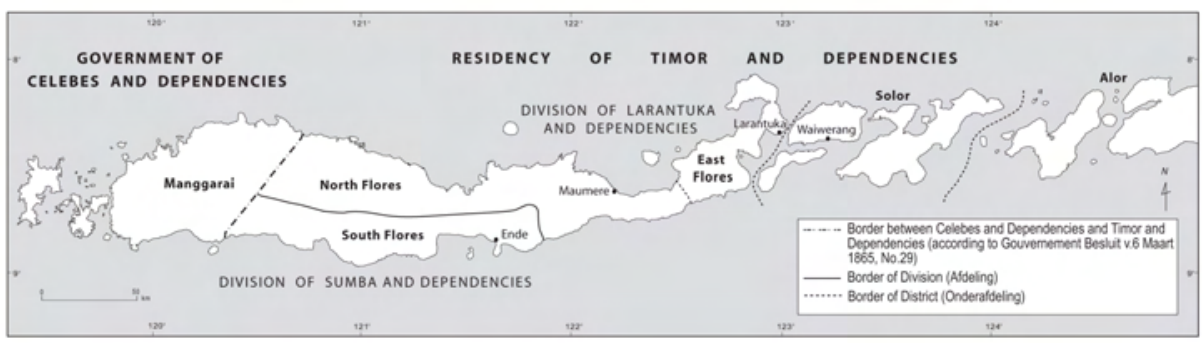

Note that this was before the Dutch had adjusted administrative boundaries to coincide with the rajadoms they later recognised on the island. Manggarai in the west was part of Gouvernement Celebes en Onderhorigheden (Government of Celebes [Sulawesi] and Dependencies) while the rest of Flores was administratively part of Residentie Timor en Onderhorigheden (Residency of Timor and Dependencies). Within the Residency of Timor, South Flores (Zuid Flores), which included Ende, most of Nage Keo and some of Ngada, was part of the Division (D: Afdeling) of Sumba and Dependencies while the rest of Flores was the Division of Larantuka and Dependencies. Larantuka was divided into the subdivisions or districts (D: Onderafdelingen) of North Flores (which included Sikka and Maumere, which the Dutch had made the administrative centre of the subdivision), East Flores, Solor and Alor. This administrative division of the island did not work too well, as a brief glance at the map might lead us to suspect, and so, in 1907, the lines were redrawn as follows (Map 6):

\section{Map 6: Dutch administrative divisions of Flores, 1907-09}

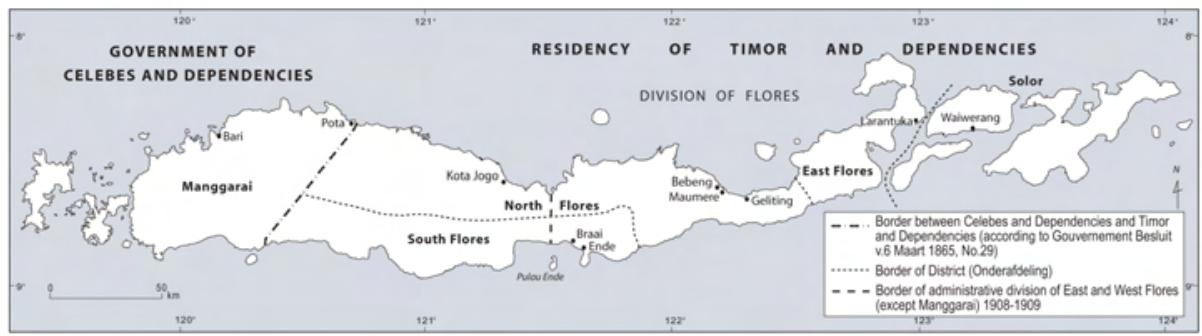

In these years (1907-09), Manggarai remained part of the Government of Celebes, while the rest of Flores was the Division of Flores and was included in the Residency of Timor. South Flores was removed from the Division of Sumba and made part of the Division of Flores, which was divided into the Subdivisions of South Flores, North Flores, East Flores and the Solor Islands. This arrangement should have worked all right, except that, in 1908, an administrative division between West Flores and East Flores was created. The new division crosscut South Flores and North Flores and must have been the source of innumerable 
headaches for the officials assigned to the island. But those headaches lasted only two years.

In 1909, the divisions of the island were shuffled once again, in such a way as to bring the administrative divisions into accord with at least some of the rajadoms on the island (Map 7).

\section{Map 7: Dutch administrative divisions of Flores, 1909-31}

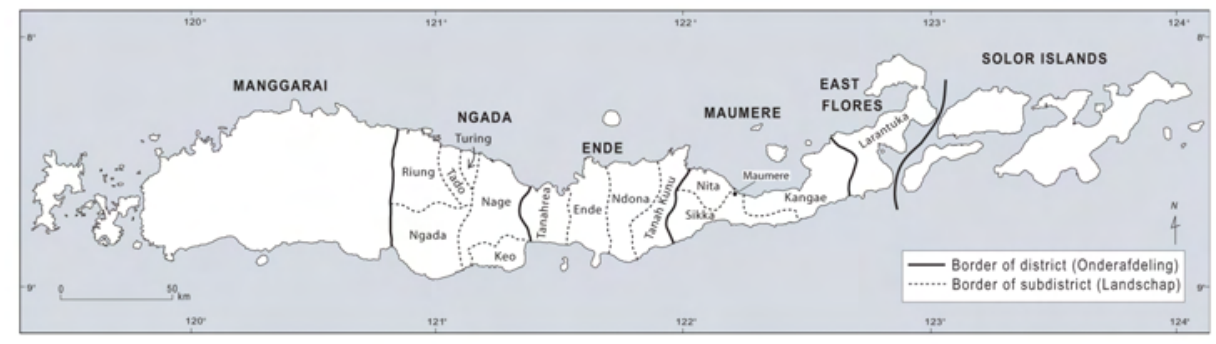

Manggarai was removed from the Government of Celebes and made a subdivision (onderafdeling) of the Division of Flores. The old divisions of South Flores, North Flores and East Flores disappeared and were replaced by subdivisions (onderafdelingen) that took greater account, though roughly, of the linguistic, social, economic and, perhaps most important, the political realities of the island. These were (in addition to the Subdivision of Manggarai) the Subdivisions of Ngada (including Nage Keo), Ende (including Lio), Maumere, East Flores (including Larantuka) and the Solor Islands. The subdivisions were further divided into districts (landschappen). Most of the names of the districts corresponded with the names of socio-linguistic groups on the island. The new district and administrative arrangements were comparatively rational, since they took account of the native rajadoms the Dutch had either recognised or created in the previous 50 years. In particular, the three rajadoms of the District of Maumere, Sikka, Nita and Kangae, were clearly demarcated. This arrangement of administrative divisions survived until about 1930, when some of the rajadoms were amalgamated.

Joachim Metzner has given us the following reconstruction of the political divisions of eastern Sikka towards the end of the 19th century. This would have been some 20 years after the earliest entries in the Dagboeken van het Controleuren van Maoemere, which were kept, more or less faithfully, by the posthouders assigned to Maumere, beginning in 1879, but before the dispute between the rajas of Sikka and Larantuka over Tana 'Ai was settled (Map 8). ${ }^{33}$ 
Map 8: Political divisions of Sikka towards the end of the 19th century and before Dutch intervention in the border dispute between Sikka and Larantuka

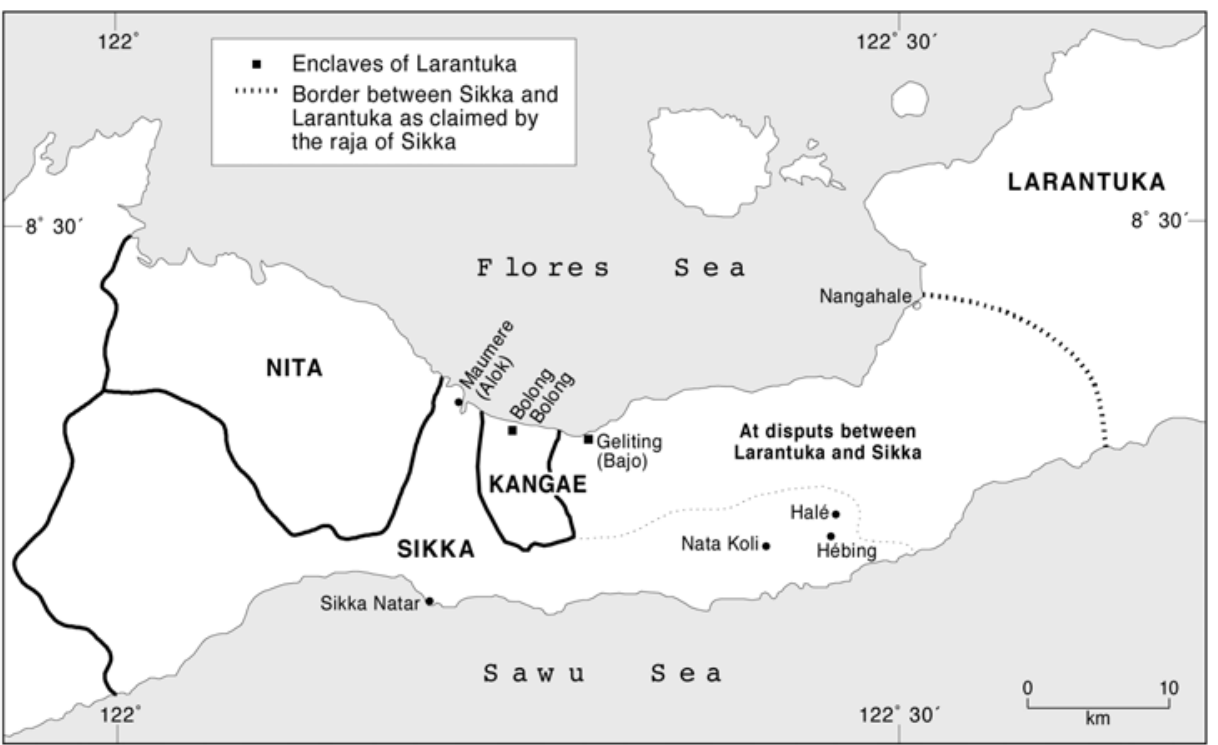

Map 9: Political divisions of Sikka in the early 20th century after Dutch intervention

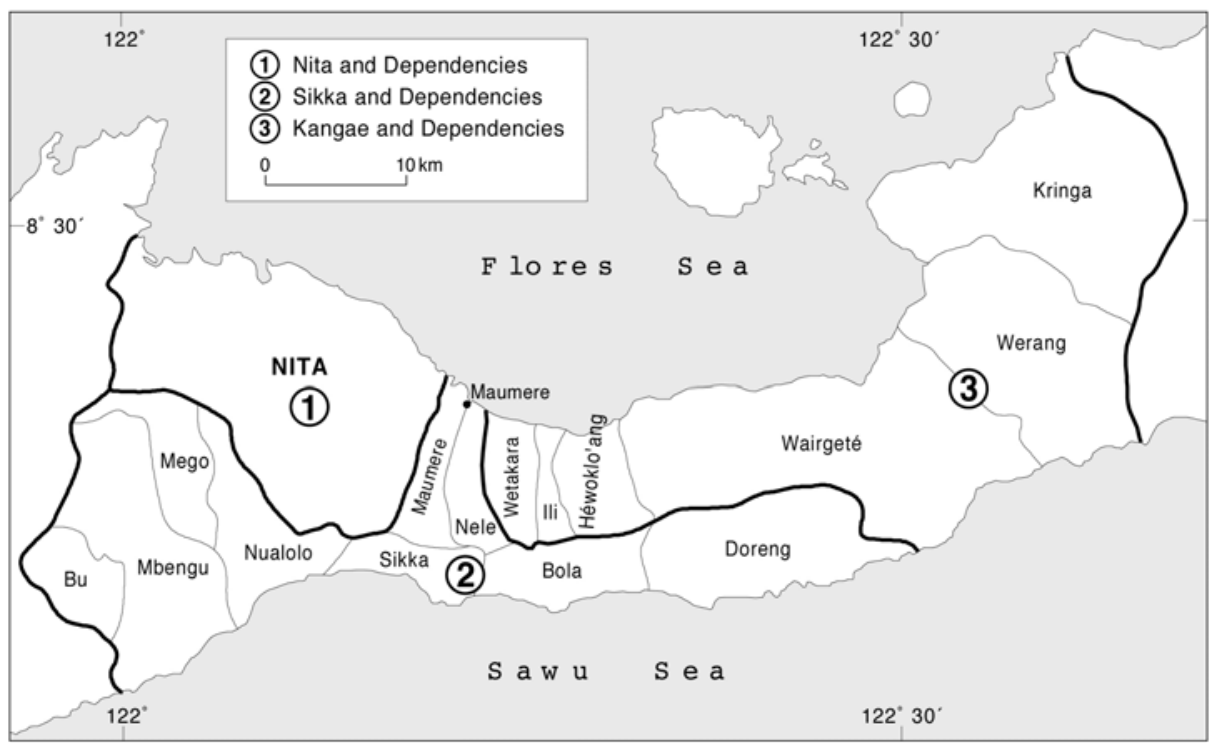


More certain are the political divisions of the District of Maumere after the boundaries established by the Dutch after they settled the Tana 'Ai dispute at the beginning of the 20th century. The settlement placed Tana 'Ai within the Rajadom of Kangae (Map 9).

Here we see plainly the way the Dutch, by 1904, recognised the indigenous polities of the Sikka region, which were ruled by the Raja of Sikka, the Raja of Nita and the Raja of Kangae. The Raja of Kangae ruled a region created by the Dutch when they could find no other way to control the subversive and overtly hostile activities of one Raja Nai against the authority of the Raja of Sikka. These boundaries - around what the Sikkanese called kapitan-schappen-correspond roughly to the kecamatan into which the kabupaten is divided today.

By 1929, the Dutch acceded to the amalgamation of the Rajadoms of Nita and Kangae into the Rajadom of Sikka, whose raja, Mo'ang Ratu Thomas Ximenes da Silva, ruled the whole of the region of Sikka until his death in 1954. The dissolution of the Rajadom of Kangae, which had been born of a rebellion against the Raja of Sikka in the first decade of the 20th century over a question of taxation, followed the enforced settlement by the Dutch of the dispute between the rajas of Sikka and Larantuka over sovereignty over Tana 'Ai, which became firmly part of the Rajadom of Sikka. The Rajadom of Nita, whose rulers were kinsmen of the Raja of Sikka, was also dissolved and its territory placed under the rule of Sikka, partly as an administrative convenience for the Dutch but also in response to the political activity and persuasiveness of Raja Don Thomas, the last of the Sikkanese rulers.

After 1931 and until the beginning of the Japanese occupation in 1942, the administrative map of Flores was as depicted in Map 10: 34

\section{Map 10: Administrative divisions of Flores, 1931 to early 1950s}

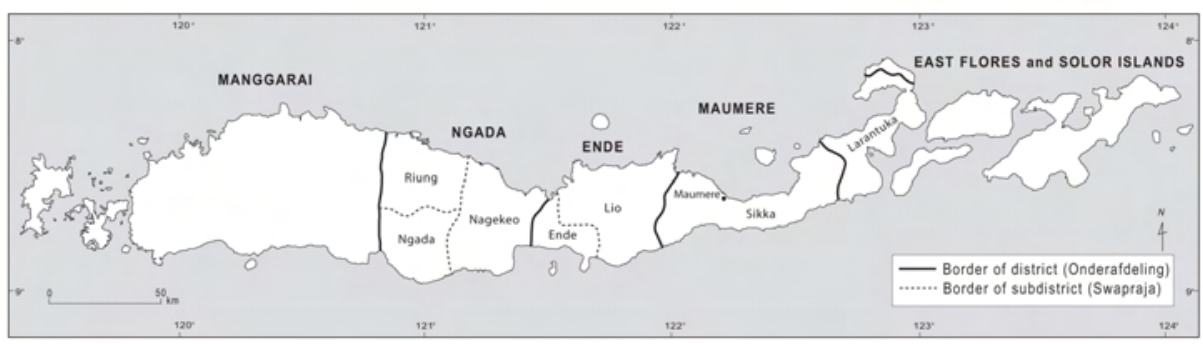

These boundaries were those of the rajadoms of Flores within the Division of Flores. Under the government of the newly independent Indonesia, the rajadoms were abolished in the early 1950s, after which the old divisions, and their boundaries, were retained as kabupaten in the new system of government. 


\section{The Reconceptualisation of Territorial Categories in Central Sikka}

It would be simple enough, but somewhat facile, to assume that local states and the territorial categories and institutions that attend them arose on Flores - and elsewhere in eastern Indonesia - when and where local communities came into sustained contact with Europeans. Certainly Europeans played significant roles in the development of local states in the archipelago of Nusa Tenggara Timur. Officers of the Dutch Government, for example, intervened in local affairs to nominate one house or another as a ruling house. But it is less clear that Europeans caused the rise of states. In any case, attributing the advent of states to the influence of Europeans does not answer the question of why it was that states arose in some places but not in others (even though those non-state regions came at some stage in their histories under the influence of or were incorporated into states). It is the case that places that experienced long and continuous contact with Europeans came to have local rulers. Examples in eastern Indonesia include Larantuka (Portuguese and Dutch) and Roti and parts of south-western Timor (Dutch). But it is less clear why communities such as Sikka, which had occasional but probably not continuous contact with the Portuguese and Dutch before the Dutch established a permanent governmental presence on the island, would have developed state structures.

In considering this question we should bear in mind two facts. Firstly, there were large-scale states in Indonesia that predated the arrival of Europeans in South-East Asia. Secondly, while the societies of eastern Indonesia were to some degree remote from the western Indonesian archipelago and mainland South-East Asia, where such states thrived in pre-European times, they were not cut off from communication with those ancient centres. Indeed, through maritime trade, courts and kingdoms such as Srivijaya, Majapahit and Mataram exerted profound and lasting influences on quite distant communities, which were neither part of their territories nor under their direct rule. In a most useful work on trade and state development in South-East Asia between 1000 and 1500 AD, Hall commented:

By the thirteenth century this Western demand [for South-East Asian spices] had greatly enhanced the commercial importance of Southeast Asia as a source of trade goods in Western eyes and as the source of valuable spices in particular. ... During this time merchants based on the Java coast carried on two kinds of external trade, a trade with East and West (primarily with India and China) in spices and other luxury goods, and an export-import trade in rice to the Moluccas and to other parts of the eastern and western archipelago in exchange for spices and cloth. ... Java's success as the intermediary of the international spice 
trade was based on a mutual dependency that came to exist between Java and the islands of the eastern archipelago. (Hall 1985: 209-10)

Hall identifies a trade network in the Java Sea as one of five South-East Asian trade zones that arose between 1000 and 1500 AD, one that included the Lesser Sunda Islands, the Moluccas, Banda, Timor, the western coast of Borneo, Java, and the southern coast of Sumatra' (Hall 1985: 226). He goes on to say: 'The new east Java-based state of Majapahit that came into existence at the end of the thirteenth century established a loose hegemony over the eastern and western archipelago' (ibid.).

In other words, models for local states in eastern Indonesia predate the European era in eastern Indonesia. Trade networks would have served not only as media for the exchange of goods, but also of ideas. While Sikka itself may not have played a central role in these networks, its location near the epicentre of an arc from south Sulawesi through the Banda Sea to Timor, which was part of those networks, would have guaranteed that its people were exposed to the people and ideas of other parts of Indonesia. When exploring the histories of eastern Indonesian states it may be fruitful to keep in mind that, whatever influence the Europeans might have had on the development of eastern Indonesian states, their origins and underlying structures might have been Indonesian.

In central Sikka, the evolution of a large number of village domains into a single polity under the rule of a raja from Sikka Natar would have required the Ata Sikka to reconceptualise categories of territory. This reconceptualisation, like much culture change in Sikka, involved not so much the redefinition of tana and negeri as the addition of a new concept of territory and new territorial categories. Thus, in 200 years of history, the Ata Sikka acquired kampung (BI: 'village'), kerajaan (BI: 'rajadom'), desa (BI: 'village-based municipality'), kecamatan (BI: 'district'), and kabupaten (BI: 'regency'), all of which were coeval with new institutions of government and administration. The tana, negeri and natar of the older Sikka had no boundaries; none, at least, until the first map-makers arrived on the scene. Although the scale of tana in central Sikka was small-perhaps as many as 45 discrete tana coexisted in an area of no more than 700 square kilometres - the reconceptualisation of the idea of territory by the addition of the concept of territory as bounded landscape to the early concept of territory as places within the fluctuating realm of a local centre of ritual power would have been considerable. It involved a shift from a social world made up of many centres of local, ritual power to that of a polity in which the raja bore a singular power that, while delegated through new institutions of government, overrode the powers of the old local centres. In those centuries, the Sikkanese brought about a profound shift from a polycentric and polycosmic to a monocentric and monocosmic culture. 
Unlike the older domains, under Dutch administration, the rajadom came to be bounded. The boundaries of the rajadom necessarily implied territories of similar constitution beyond those boundaries, and thus a sense of Sikka as a part of Flores and as a part of a larger political entity. The rajadom introduced new institutions that evolved mutually with the new concepts and a new hierarchy of officeholders whose authority encompassed all the old domains. Thus a wholly new system of status and prestige came into being within which, in later years, the authority and power of district officers and ministers in the raja's government all but completely eclipsed those of the ritual leaders of the domains. The old offices of tana pu'ang and ritual specialists survived, but their main function came to be the legitimation of the new order. It may be worth quoting here an observation I made in one of my earliest publications on Sikka:

There is a striking similarity between the character of the ritual office of tana pu'ang in Sikka [Natar] and the Dae Langgak of the Rotinese domains. In Sikka, as on Roti, the tana pu'ang claims priority of authority because of earlier presence. The present tana pu'ang of Sikka Natar recounts that his forebears actually created the Sikkanese rajadom by nominating one Sikkanese lineage as that of the ratu [raja]. ${ }^{35}$ As on Roti, the Sikkanese tana pu'ang, except in his role as ritual lord of the earth, is treated by members of the community (especially by those of the noble lineages) as socially inferior and something of a buffoon (Fox 1980: 109). To be sure, the office of the tana pu'ang in Sikka Natar has survived the institution of the rajadom by many years. (Lewis 1988: 318, footnote 9)

Although there are men in the villages of central Sikka who still claim the position, few modern Sikkanese can identify the tana pu'ang of their home villages. Yet it is the case that, in modern Maumere, events occasionally occur in which it is necessary for someone to act in the capacity of tua adat (ritual specialist). When such an event occurs it is rare for anyone with a link to one of the old ceremonial systems of central Sikka to serve. Most frequently, a knowledgeable retired schoolteacher or other student of Sikkanese history and culture assumes the role of tana pu'ang on occasions such as the funerals and marriages of influential people. 36 Thus the concept of the tana pu'ang as efficacious ritualist who personifies the order of a domain persists in modern times among the most sophisticated Sikkanese and in a society whose contemporary political and economic structure is that of a kabupaten derived from a rajadom.

\section{Acknowledgment}

Map 3 is redrawn from Metzner (1982: 112), and Maps 5-10 are redrawn from Metzner (1982: 72, 73, 79 and 82). 


\section{References}

Burling, Robbins. 1965. Hill Farms and Padi Fields: Life in Mainland Southeast Asia. Englewood Cliffs (New Jersey): Prentice-Hall.

da Franca, A. P. 1970. Portuguese Influence in Indonesia. Jakarta: Gunung Agung. de Sá, Artur Basílio 1956. Documentaçã para a Histõria das Missões do Padroado Português do Oriente. Insulíndia 4. ${ }^{\circ}$ Vol. (1568-1579). Lisboa: Agência Geral do Ultramar, Divisão de Publicações e Biblioteca. P. 480.

Echols, John M. and Hassan Shadily.1989. An Indonesian-English Dictionary. Third Edition. Ithaca: Cornell University Press.

Fox, James J. 1980. 'Obligation and Alliance: State Structure and Moiety Organisation in Thie, Roti.' In J.J. Fox (ed.), The Flow of Life: Essays on Eastern Indonesia, Cambridge (Mass.): Harvard University Press. pp. 98-133.

Hall, Kenneth R. 1985. Maritime Trade and State Development in Early Southeast Asia. Honolulu: University of Hawai'i Press.

Kondi, D.D.P. Unpublished [2001]. 'Hikayat Kerajaan Sikka (History of the Rajadom of Sikka).' E.D. Lewis and Oscar Pareira Mandalangi, editors and translators.

Lewis, E.D. 1988. People of the Source: The Social and ceremonial Order of Tana Wai Brama on Flores.' Verhandelingen van het Koninklijk Instituut voor Taal-, Land-en Volkenkunde, 135. Dordrecht: Foris Publications.

Lewis, E.D. 1996a. 'Origin Structures and Precedence in the Social Orders of Tana 'Ai and Sikka.' In James J. Fox and Clifford Sather (eds), Origins, Ancestry, and Alliance: Explorations in Austronesian Ethnography. Canberra: Monographs of the Department of Anthropology, The Australian National University.

Lewis, E.D. 1996b. 'Invocation, Sacrifice, and Precedence in the Gren Mahé Rites of Tana Wai Brama, Flores.' In Signe Howell (ed.), For the Sake of Our Future: Sacrificing in Eastern Indonesia, Leiden: CNWS Publications, Vol. 42.

Lewis, E.D. 1998a. 'The Tyranny of the Text: Oral Tradition and the Power of Writing in Sikka and Tana 'Ai, Flores.' Bijdragen tot de Taal-, Land-en Volkenkunde, 154 (3). pp. 457-77.

Lewis, E.D. 1998b. 'Don Alésu's Quest: The Mythohistorical Foundation of the Rajadom of Sikka.' History and Anthropology, Vol. 11 (1). pp. 39-74.

Lewis, E.D. 1999. 'The Encyclopædic Impulse: Accounts of the Origin of the Rajadom of Sikka by Two Sikkanese Authors.' Bijdragen tot de Taal-, Land-en Volkenkunde, 155 (3). pp. 543-78. 
Lewis, E.D. In press. 'Precedence and Hierarchy in the Formation of Tana Wai Brama and the Rajadom of Sikka.' In Michael P. Vischer (ed.), Precedence and Social Differentiation in the Austronesian World, Canberra: Monographs of the Department of Anthropology, Research School of Pacific and Asian Studies, The Australian National University.

Lewis, E.D., Timothy Asch and Patsy Asch. 1994. A Celebration of Origins. 16mm film. Watertown, Massachusetts: Documentary Educational Resources, Inc.

Meersman, A. 1967. The Franciscans in the Indonesian Archipelago, 1300-1775. Louvain: Nauwelaerts.

Metzner, Joachim K. 1982. Agriculture and Population Pressure in Sikka, Isle of Flores: A Contribution to the Study of the Stability of Agricultural Systems in the Wet and Dry Tropics. Development Studies Centre Monograph No. 28. Canberra: The Australian National University.

Pareira, Alexius Boer. Unpublished [2002]. 'Notes on Hadat Sikka from the 1940s and 1950s by Mo'ang Alexius Boer Pareira.' Transcribed, translated and edited by E.D. Lewis and Oskar Pareira Mandalangi.

Pareira, M. Mandalangi. 1992. Kerajaan Sikka, Nita, Kangae Masa Lampau. Maumere: Mimeograph by author.

Sejarah Gereja Katolik Indonesia, Jilid 1. 1974. Ende-Flores: Percetakan Arnoldus.

Visser, B.J.J. 1925. Onder Portugeesch-Spaansche Vlag: De Katholieke Missie van Indonesië 1511-1605. Amsterdam: N.V. de R.K. Boek-Centrale.

Wilkinson, R.J. 1959. A Malay-English Dictionary (Romanised). London: Macmillan.

\section{ENDNOTES}

1 Some of the research material on which this paper is based was first presented in the Comparative Austronesian Studies Workshop, Sharing the Earth, Dividing the Land: Territorial Categories and Institutions in the Austronesian World, June 18-19, 2001, Canberra, The Australian National University, Research School of Pacific and Asian Studies. The version published here was drafted in 2003 and completed while I was Visiting Professor of Anthropology in the Department of Social Anthropology, University of Bergen, Norway, in 2004. I wish to thank Professors Edvard Hviding and Bruce Kapferer and Associate Professor Olaf H. Smedal for arranging my visit to Bergen and for the support I received while I was a member of their department.

${ }^{2}$ Kabupaten is an administrative division of the Indonesian State below the level of province. The word translates as 'regency.'

3 I exclude the communities of Lamaholot-speaking people in the north-eastern region of the regency, which the Sikkanese refer to as Muhang, and the Lionese population of the far western and south-western region of the kabupaten.

4 See Lewis (1996a) for a genealogy of the rajas of Sikka.

${ }^{5}$ See Lewis (1996a and in press) for discussions of precedence in the social orders of Tana 'Ai and Sikka.

6 The gren mahé, or celebration of the mahé, is the culminal rites of the ceremonial system of a Tana 'Ai domain. The gren requires the sacrifice of animals by all of the domain's clans and houses and, thus, the participation of all of the domain's people (see Lewis 1988, 1996b; and Lewis, Asch and Asch 1994). 
7 Note also the Sara Sikka word klo'ang, which is a small village or hamlet in Sikka and, in Tana 'Ai, a hamlet composed of clan and ritual houses.

8 Note the modern graves bearing Christian symbols interspersed with the stones of the mahés at Héwoklo'ang (Plate 1) and Baomékot (Plate 2) and the juxtaposition of a cannon (provenance unknown) and the stones of the small mahe in the village of Kangae (Plate 3).

9 These works (Kondi unpublished [2001] and Pareira unpublished [2002]) are two of more than 90 manuscripts that make up a collection of works by Kondi, Boer and other Sikkanese authors. The collection and the histories of the Rajadom of Sikka, which are their principal subject, are described in Lewis (1998a, 1998b and 1999).

10 The text of the chart is incomplete: the suku (clan) affiliation of the Kapitang Salaf is not specified (although space has been left for it to be added) and the original diagram, which was written in pencil, has been amended at least twice, once with writing in blue ink.

11 Sikka contrasts with the communities of the Tana 'Ai domains, in which sukun (clans) are the major social groups.

12 I am indebted to Dr Alan N. Baxter of the University of Macau, an authority on Portuguese linguistics and Portuguese creoles in Africa, South America and South-East Asia, for assistance with these notes and for pointing out to me the linguistic significance of the borrowings from Portuguese that are found in Sara Sikka.

a $D u^{\prime} a$ mo'ang are leaders and ritual specialists.

13 Puho and Rohé, for example, appear in group 1 and group 10 while Nata Koli appears in groups 2 and 9.

a The gift of twin elephant tusks, mangung lajar (mast and sail), to cement alliances between the rajas of Sikka and the negeri (villages) of the district, is a recurring theme in Boer's and Kondi's texts of the mythic histories of the Sikkanese rajadom.

b Tahi La'i (the Male Sea) and Tahi Wai (the Female Sea) are the Savu Sea and the Flores Sea, respectively.

14 In the modern system of government divisions, a kecamatan is a district within a kabupaten.

${ }^{15}$ In places, Metzner uses the old representation tana puäng, whereby the intervocalic umlaut represents a glottal stop, for tana pu'ang. Elsewhere he spells the words tana puang, but note that puang and pu'ang are different words in Sara Sikka.

16 Adat (BI), 'custom, tradition; customary law'.

17 Metzner carried out his field research in Sikka in the 1970s, shortly before I began my fieldwork in Sikka Natar and Tana 'Ai in late 1977. He notes that he based the tana boundaries depicted in his map on oral and written information provided by informants who included A. Boer Pareira at Bola. I have been unable to locate copies of the unpublished documents he cites in this section of his book.

18 This map is redrawn from Metzner (1982: 112). A few corrections have been made, but otherwise the tana names are as Metzner recorded them. As will be argued below, it is likely that the tana of Sikka changed through time, which means the enumeration of tana and reconstruction of tana centres and possible boundaries is extremely difficult and, at best, speculative. I hope to publish another map of Sikka's tana and a tentative reconstruction of their evolution in the future.

19 That is, the tana from and including Egong to the east and those east of and including Natarwulu (which is properly Natarwalu), Teru and Wolo'lora to the west.

20 Burling's formula holds true for Sikka, except that the linguistic differences among the Sikkanese are those of dialects rather than languages.

21 I.e., 'matriarkal' rather than patrilineal, pagan rather than Catholic, simple rather than educated and sophisticatedly cosmopolitan, and rather easily snookered in their dealings with the outside world. The gentleman went on to outline how Tana 'Ai might have a fence built around it and be set aside as a 'cadangan budaya dan sejarah,' a 'culture and history reserve'. His thinking was this: since we Sikkanese have become modern, and since the Ata Tana 'Ai are the way we used to be and have not changed, we Sikkanese can preserve our history and traditional culture by preserving Tana 'Ai as a kind of living museum.

22 'Iwang Geté was (and still is) the region of Kecamatan Kéwapante on the north coast and to the east of Maumere, including the coastal town of Geliting and the negeri of Watublapi, Héwoklo'ang, Baomékot, Ohé, Klo'ang Popot, Halé, and Hébing. Krowé is another name for the hill region of central Sikka, including the negeri of Nita, Koting, Nele, Tilang, Ribang, Dokor, Ili, Kéwapante, Habi and Bola. Ata Krowé are also called the Ata 'Iwang by the Sikkanese. 'Iwang Geté (Greater 'Iwang) included Watublapi, Héwoklo'ang, Baomékot, Ohé, Klo'ang Popot, Halé, and Hébing. 
23 See Lewis (1998b and 1999) for treatments of the origin myth of the ruling Sikkanese and Lewis (1998b) for details of this episode in the myth.

24 References to Kerajaan Sikka as Swapradja Sikka are found occasionally in the literature on Sikka in the first half of the 20th century. Swapradja (swapraja in the new spelling) were autonomous areas or regions.

25 The genealogy of the rajas of Sikka account for 18 rajas, beginning with Don Alésu. Before Don Alésu there were 13 generations of Sikkanese leaders, the last three of which can be described as proto-rajas. These were Mo'ang Bata Jawa, Mo'ang Igor and Mo'ang Baga Ngang, Mo'ang Alésu's father (see Lewis 1998b).

26 See Franca (1970) for references to the Portuguese influence in Sikka.

27 Meersman (1967: 37) documents the arrival of three Franciscan friars at Ende in 1589.

28 That is, Krowé; see footnote 25. Dondo is not a placename in contemporary Kabupaten Sikka.

29 The information Visser cites derives from a compilation by Joao dos Santos OP, a Dominican missionary who worked in Mozambique and elsewhere and who died in 1622 in Goa. The data were published in a book entitled Ethiopia Oriental, which dos Santos completed ca. 1599 and to which he added notes as late as 1606. The book was reprinted in 1891 in Lisbon and from it another priest, P. Bierbaum, published a summary of information about the Solor missions in Zeitschrift für Missionswissenschaft (1924: 19) (Sejarah Gereja Katolik Indonesia 1974: 377).

30 The mythic histories of Sikka attribute the first conversions of Sikkanese to Catholicism to a Malaccan named Augustinu (or Augustinus) Rosario da Gama, the son of a Malaccan ruler identified as Raja Worilla. Da Gama accompanied the first Raja of Sikka, Alexius Don Alésu da Silva, on his return to Sikka after a stay in Malacca, where Alésu converted to Christianity and studied religion and government. In a mimeographed essay on the rajadoms of Sikka, Nita and Kangae, M. Mandalangi Pareira (1992) summarises the arrival of Catholic missionaries in Sikka. Pareira cites a Dominican report that mentions a church named Santa Lusia (Lucia) with a congregation of 1000 souls at Sikka in 1598 and identifies the church at the station at Dondo on the north coast of Flores as Santa Maria da Boa Virgem. This information is found in Visser (1925), but Pareira does not cite Visser and the source of his information is unclear.

31 'Averá nesta ilha de Larantuca, entre a provoação prinçipal, que se chama deste proprio nome, e outra está pella ilha adiante, quinze legoas, a que chamão Siqua, e outra que chamão Pagua, e o Ende, que está outras quinze adiante; todas de christãos, obra de mil espingardas, e melhoria dellas, allem de outras muitos christãos e gentios, amigos nossos, com as armas que assima fica dito' (Sa 1956: 480). It is worth noting that the people of Sikka Natar themselves assert that their ancestors converted to Catholicism in 1552.

32 Memories van overgave (D: memoranda of handing over or transmission) were reports written by Dutch civil servants who had served in a district as sources of information for officials newly appointed to the district. These reports contained social, political, geographic and economic information compiled by an outgoing official on the district for which an incoming official would assume responsibility.

33 The Dagboeken were diaries kept by the leading Dutch officials (posthouders) in Maumere from 1879.

34 It is unclear to me whether the Japanese altered in any way the administrative territories elsewhere on Flores, but the boundaries of the Rajadom of Sikka were not changed under Japanese occupation.

35 Recall that Kondi's manuscript history of the rajadom includes episodes of the origin myth of the Sikkanese rajadom in which the earliest rajas are credited with creating the region's tana and tana pu'ang.

36 A striking example of such an event occurred in 1994 when a ceremony was held in Maumere to repair a 50-year-old rift between two branches of the Royal House of Sikka. On that occasion, a retired school teacher, an elderly man from Sikka Natar who is recognised widely as one of the regency's leading authorities on the history and adat of Sikka, presided over the agenda and performed the animal sacrifices by which the rift was healed. Officials of the regency government were seated among the scores of invited onlookers in the house yard rather than with the parties to the ritual on the verandah of the house where the ritual was performed, an arrangement the significance of which was missed by no one present. 